\title{
Integrated Decision Support Models for Sustainable Groundwater Management in Crystalline Hard Rocks: Implications for Sugarcane Agriculture
}

\section{Syed Adil Mizan}

NGRI: National Geophysical Research Institute CSIR

Sahebrao Sonkamble ( $\nabla$ sahebrao@ngri.res.in )

National Geophysical Research Institute CSIR https://orcid.org/0000-0002-6013-6183

Adarshya Sharadha

NGRI: National Geophysical Research Institute CSIR

Md. Wajihuddin

Government of Telangana

Sumit Roy

WWF-India

Murli Dhar

WWF-India

\section{Research Article}

Keywords: Sugarcane agrarian, Groundwater irrigation, Hydro-geophysics, Decision support tool, Granitic aquifer, India

Posted Date: May 5th, 2021

DOI: https://doi.org/10.21203/rs.3.rs-456222/v1

License: (c) (i) This work is licensed under a Creative Commons Attribution 4.0 International License.

Read Full License 


\section{Title Page}

Integrated decision support models for sustainable groundwater management in crystalline hard rocks: Implications for sugarcane agriculture

Syed Adil Mizan ${ }^{1}$, Sahebrao Sonkamble*,1, Adarshya Sharadha ${ }^{1}$, Md. Wajihuddin ${ }^{2}$, Sumit Roy ${ }^{3}$, Murli Dhar ${ }^{3}$

${ }^{1}$ CSIR-National Geophysical Research Institute, Uppal Road, Hyderabad 50007, India

${ }^{2}$ Telangana State Groundwater Department, Hyderabad 500061, India

${ }^{3}$ WWF-India, 172 B, Lodhi Estate, New Delhi- 110003 India

* Corresponding Author: Dr. Sahebrao Sonkamble, E-mail: sahebrao@ngri.res.in, Tel +91 9441455291 


\title{
Integrated decision support models for sustainable groundwater management in crystalline hard rocks: Implications for sugarcane agriculture
}

\begin{abstract}
:
India is second largest sugarcane producing nation with water foot prints $\sim 104 \mathrm{BCM} / \mathrm{year}$ of which $80 \%$ met from groundwater of deep-wells. The large-scale groundwater management practices were found mostly untenable affecting the sugarcane agrarian and associated sectors. We developed a cell-level $(2 \mathrm{~km} \times 2 \mathrm{~km})$ decision support tool (DST) employing the integrated hydro-geophysical investigations in sugarcane agro-watershed (399 sq.km) beset over granitic aquifer systems of Tattihalla River watershed, Southern India. The refined hydrogeological conceptual model derived from electrical resistivity tomography (ERT) and groundwater level (head) has been accounted into the numerical modelling. The model was run on transient mode for four stress periods during 20152017 and validated with calculated and observed heads. The normalized RMS error $7.57 \%$ of the validated model conveys its robustness and estimates groundwater budget at the demarcated 77 cells. The theoretical scenarios for water level projections against the increased groundwater pumping rates of $10 \%, 25 \%$ and $50 \%$ were generated. It showed declining trend of water level for projected 10 years period with varied magnitude and vulnerability for drought conditions. The different time periods of water level touching the basement (i.e. dry borewell), infers a distinct hydrogeological property of an individual cell advocating to adapt a cell level management plan. In this article, we explained two cells (Nos. $12 \& 60$ ) in detail to show the varying characteristic of aquifer against the different pumping rates.
\end{abstract}

Keywords: Sugarcane agrarian; Groundwater irrigation; Hydro-geophysics; Decision support tool; Granitic aquifer; India

\section{Introduction}

India is agrarian-based nation where water resources are the critical input in nearly all its aspects having a determining effect on the eventual food yield (Sarwar et al. 2010, Dhawan et al. 2017). About $80 \%$ of agriculture water requirement is met through groundwater in India (Shrivastava et al. 2011). In the northern India, the potential groundwater resources occur in Indo Gangetic Plain (IGP) with enhanced groundwater recharge (Sonkamble et al. 2020). However, a regional scale studies using GRACE satellite data together with hydrological model have reported a huge loss of groundwater resources in northern India (Tiwari et al. 2009). In peninsular India (Southern India), the semi-arid climatic conditions (Fishman 2018), granitic hard rocks aquifer (Sishodia et al. 2016, Maréchal et al. 2018), and channelized recharge sites and aquifer compartmentalization (Nicolas et al. 2019) have prompted to opt groundwater as the only source of irrigation resulting expansions of groundwater critical zones (Sonkamble et al. 2014). Sugarcane is one of the major cash crop of the country and occupy $3 \%$ of the total cultivated area in India. The sector supports livelihood of 50 million farmers and their families (NITI Ayog, 2020). Globally, India ranks second (next to Brazil) in terms of sugarcane production with a total production of 405 million tons (Bordonal et al. 2018; WDS 2019). Sugarcane is water intensive, largest biomass based crop, majorly

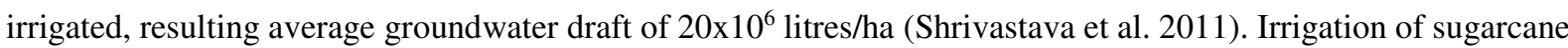
area has been increasing since 1980 by $80 \%$ to $93 \%$ of the total sugarcane-cultivated area (Shrivastava et al. 2011). 80 per cent of the irrigation requirements of sugarcane in India are met through groundwater sources. Sugarcane 
is grown over an area of 5.2 Mha requiring about 104 BCM of water/yr (Bhattacharya 2010, Srivastava et al. 2011). Sugarcane producing regions have more than $80 \%$ groundwater irrigation through deep-well. As per CGWB (2011) reports, only $162 \mathrm{BCM} / \mathrm{yr}$ of groundwater is available for future irrigation and of this about $40 \mathrm{BCM} / \mathrm{yr}$ is available in the sugarcane producing states alarming the future water crisis. It necessitates judicious consumption of groundwater resources for sustainable development which is possible through small scale groundwater management plans.

In hard rock terrains, the groundwater management is the key issue as the overexploitation has constrained the groundwater to the subsurface fractures at deeper depths. The large-scale mapping of fractured network is successfully delineated in granitic terrains using airborne electro-magnetic scans (Chandra et al. 2019). However, the complexity of the subsurface fractured network required to be understood at local scale in view of efficient groundwater management. The present situation of groundwater depletion in crystalline hard rock is attributed to inappropriate and largescale management strategies which necessitate a participatory and scenario-based strategy. To address such challenge, there are few decision support systems (DSS) based model which are computational system that uses data and models interactively to aid in the formulation, analysis, and selection of management strategies (Pierce, 2016). Sophocleous and Ma (1998) provided one of the earliest groundwater DSS that evaluates the impact of salt water intrusion on aquifer yield and Janža MA (2015) suggest DSS for emergency response to groundwater resource pollution in an urban area. The DSS has been applied for optimal estimation of groundwater availability (Uddameri et al. 2013) and groundwater governance for sustainable cities (Howard 2014). Since 1997 interest in DSS applications has been increased (Jamieson 1997) with some lump model without consideration of spatial dimension (Naik and Awahthi, 2003; National Research Council 1997). But these efforts lack the credibility of groundwater model due to heterogenous groundwater system. Recent studies conducted in African, European and Indian basements (e.g, Omorinbola 1982, 1983; Wright 1992; Chilton and Foster 1995; Owoade 1995; Wyns et al. 1999; Taylor and Howard, 2000; Maréchal et al. 2004; Dewandel et al. 2006; Krásný and Sharp, 2007; Maréchal et al. 2007, Courtois et al. 2008, Courtois et al. 2008, 2010; Dewandel et al. 2010, 2012; Maurya et al. 2021) showed that when hard rocks are exposed to regional and deep weathering processes, the geology can be considered as homogenous, the aquifer is constituted of two main sub-parallel hydrogeological layers, namely the saprolite, a clayey-sandy material, and the fissured layers, generally characterized by a dense horizontal fissuring in the first few meters and a depth-decreasing density of fissures. Based on this conceptual model of hard rock aquifer, a decision support tool (DST) was introduced by Dewandel et al. (2010) for groundwater management at watershed scale using water table fluctuation method and groundwater budget equation which is also a lump model. Their output model produced water level under different pumping and recharge scenarios at the watershed scale, i.e. average value of the watershed. Its field level implications discourage the users to apply the DST on large scale such as watershed level.

Mizan et al. 2019b developed a tool to estimate 3-dimensional specific yield and 2-dimensional groundwater recharge in deep weathered crystalline aquifer. It assumes, a net flux of groundwater to the systems is negligible at certain threshold cell size which depends draft and aquifer properties. To take the motivation from here, a groundwater management tool has been developed with the integration of numerical modelling in the present study. The numerical model has been integrated to deal with the hydraulic boundary condition at decisive cell scale which were lacking in the Mizan et al. 2019b tool. The study output of groundwater budget components 
from the numerical model has been interfaced with Dewandel et al. (2010) model for the generation of the different scenario with changing groundwater abstraction. In the present study, Tattihalla River watershed in Southern India has been selected for the validation of this approach. The area has been discretized into $2 \mathrm{~km} \times 2 \mathrm{~km}$ for the decisive groundwater management at cell scale.

The present research work focuses on the development of simple and cost-efficient groundwater management tool for the projection of water level at decisive small scale $(2 \mathrm{~km} \times 2 \mathrm{~km})$ based on the change in groundwater abstraction rate and recharge with the integration of numerical model. In this study we developed an integrated decision support tool (DST) for implementation at farm level groundwater management system. The idea is to make this model more user friendly for the farm groups, practitioners and farm extension service providers who may take their decisions for crop cultivation according to the availability of the groundwater resources.

\section{About the study area}

Tattihalla River watershed of $399 \mathrm{~km}^{2}$ located in Haliyal Taluk of Uttar Kannada district, Karnataka State, India has been selected to study the aquifer systems and their dynamic processes with special reference to sugarcane crop (Fig. 1). The study area falls in the Survey of India (SOI) Toposheet No. 48I/16, 48I/15, 48I11 and lies within

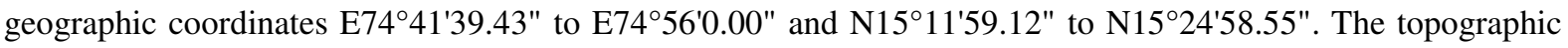
elevation varies from $484 \mathrm{~m}$ to $744 \mathrm{~m}$ above MSL with gentle slope towards south (Fig. 2a). The land use and land cover of the study area shows, next to forest land a significant area is belong to agriculture farms $(12,209 \mathrm{ha})$ of which sugarcane cultivation accounts for 1,727 ha (Fig. 2b). Agricultural irrigation in the study area is totally depended on the groundwater resources. A large number of borewells are employed for the irrigation of sugarcane, rice and vegetables. More than $80 \%$ groundwater abstraction are used for the sugarcane cultivation by flooding technique.

Geologically the area lies in the Western Dharwar Craton which comes under Chitradurga Group of Archaean to lower Proterozoic age. Major rock types of the area include metamorphosed Quartz-Chlorite Schist, Gabbro/Dolerite dykes and Banded magnetite quartzite intrusions are also exposed in the watershed (Nath et al. 1976; Chadwick et al. 1981, 1997, 1997). Hydrogeologically, the study area is drained by Tattihalla River drainage network. The aquifers occurs in semi-confined to confined conditions with deep groundwater level. The deep groundwater level below 30-50 $\mathrm{m}$ is an indication of over exploitation of groundwater resources and poor recharge process. In the study area the potential groundwater zones are limited to fractures (Fig. 3e-f). The electrical resistivity tomography (ERT) surveys in the watershed, the soil profile is subdivided into top soil, weathered zone and semi-weathered to fractured zone. 


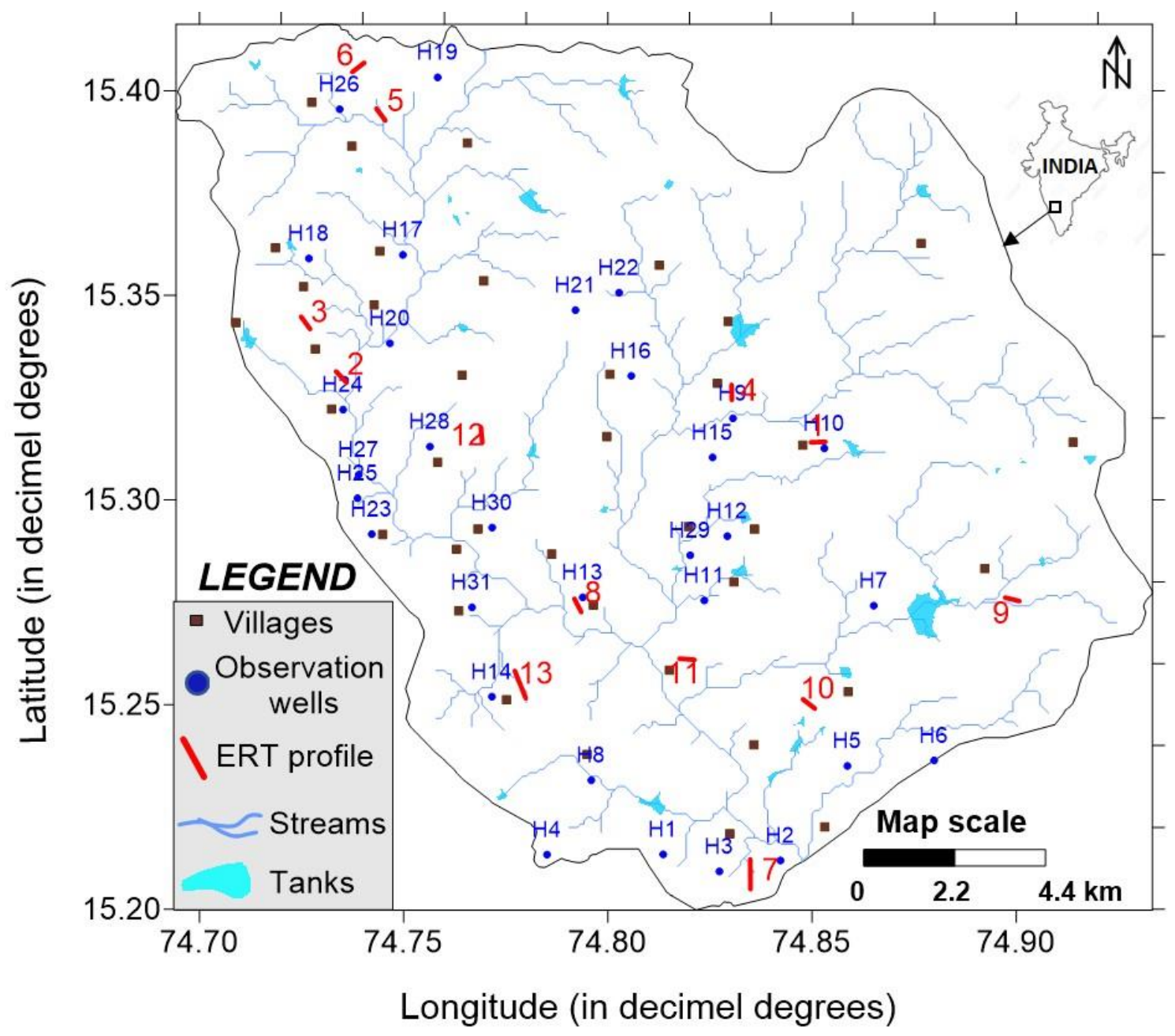

Fig. 1 Location map of the study area including the hydro-geophysical investigations 
(a) Digital elevation model (DEM)

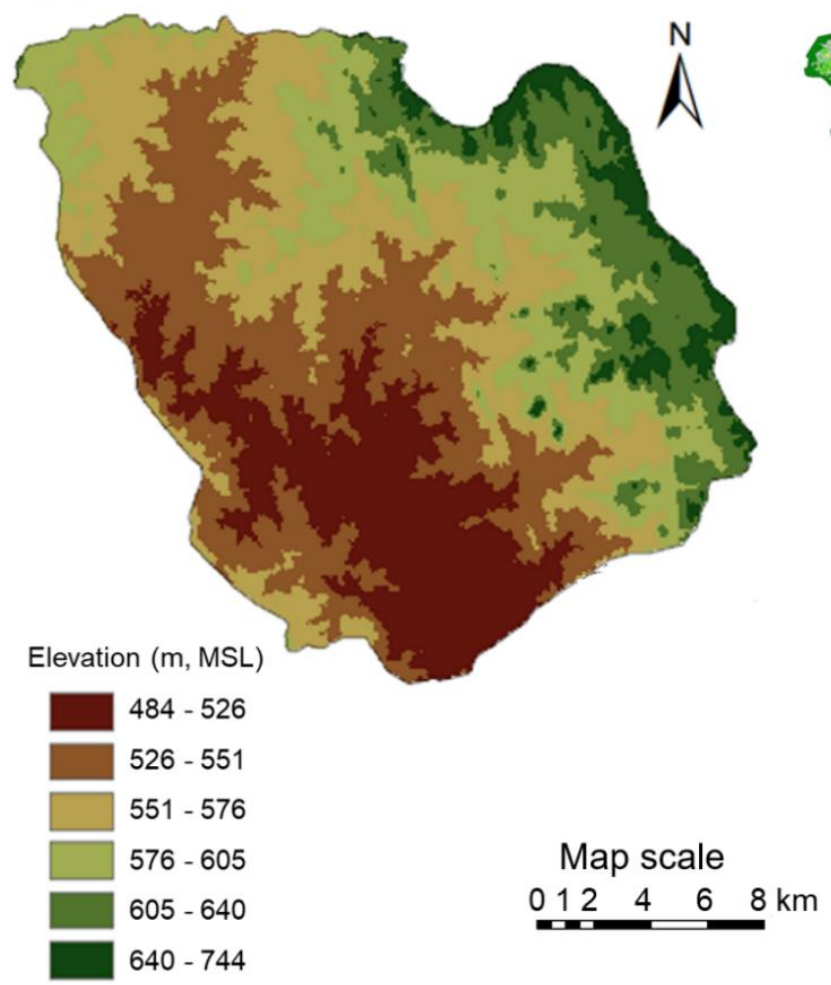

(b) Land use land cover (LULC)

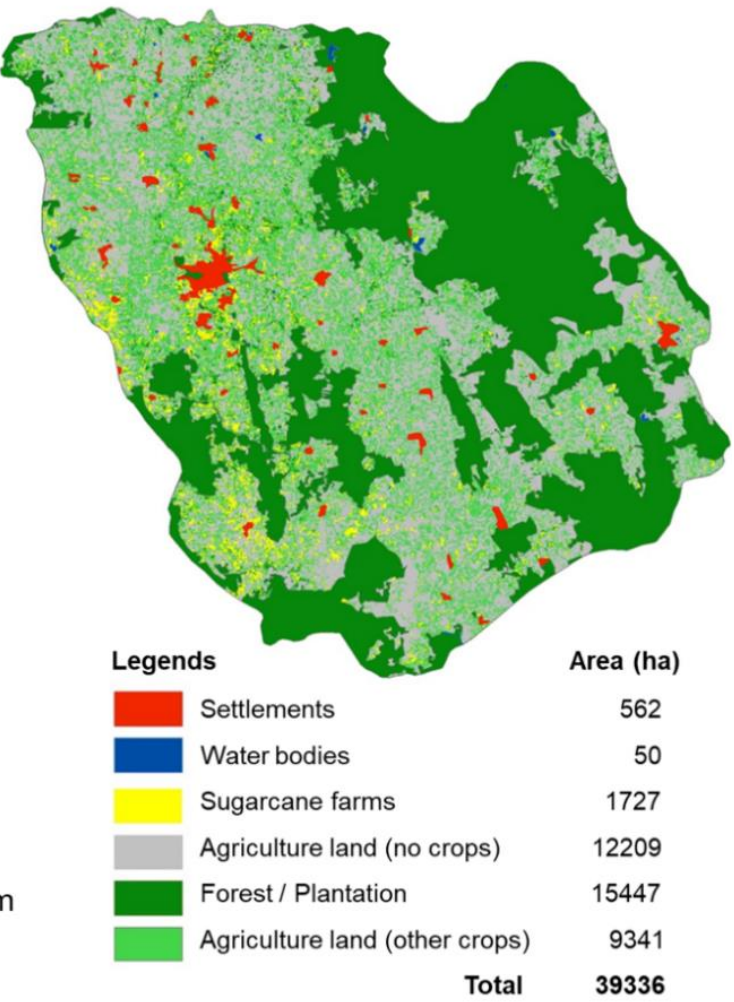

Fig. 2 Images showing, (a) digital elevation model (DEM) derived from SRTM data, and (b) land use and land cover (LULC) of the study area derived from IRS LISS-III satellite image

\section{Materials and methods}

The approach of the study involves an integrated hydro-geophysical investigation comprising well inventory, geological and hydrogeological surveys, electrical resistivity tomography and land use land cover. The field acquired hydro-geophysical data has been interpreted and fed to groundwater modelling studies for cell level characterization in term of groundwater budget and simulation of future water level. Further, the aquifer characteristics such as hydraulic conductivity, transmissivity, recharge and pumping data has been fed to decision support tool (DST) for generating the cell level future water level scenarios against varied recharge and pumping patterns. The contour maps prepared using Golden Software Surfer (V. 10.0), groundwater modelling was run on visual MODFLOW and the DST was developed on MS Excel platform. The detailed approach is described in the subsequent sections.

\subsection{Hydrogeological surveys}

\subsubsection{Well inventory}

A total of 31 observation wells were established for the periodic monitoring of groundwater levels for four stress periods (pre- and post-monsoon) of two hydrological cycles during April-2015 to May-2017 (Fig. 1). The depth to water level below ground level (bgl) and water level elevation above mean sea level (amsl) map were drawn using the field observed water level data during the study period. The water level was measured using water level 
sounder (Encardio Rites make, Model: EPP-10/6) (Fig. 3) and geo coordinates recorded by handheld GPS (Garmin make, Model: Montana 650)
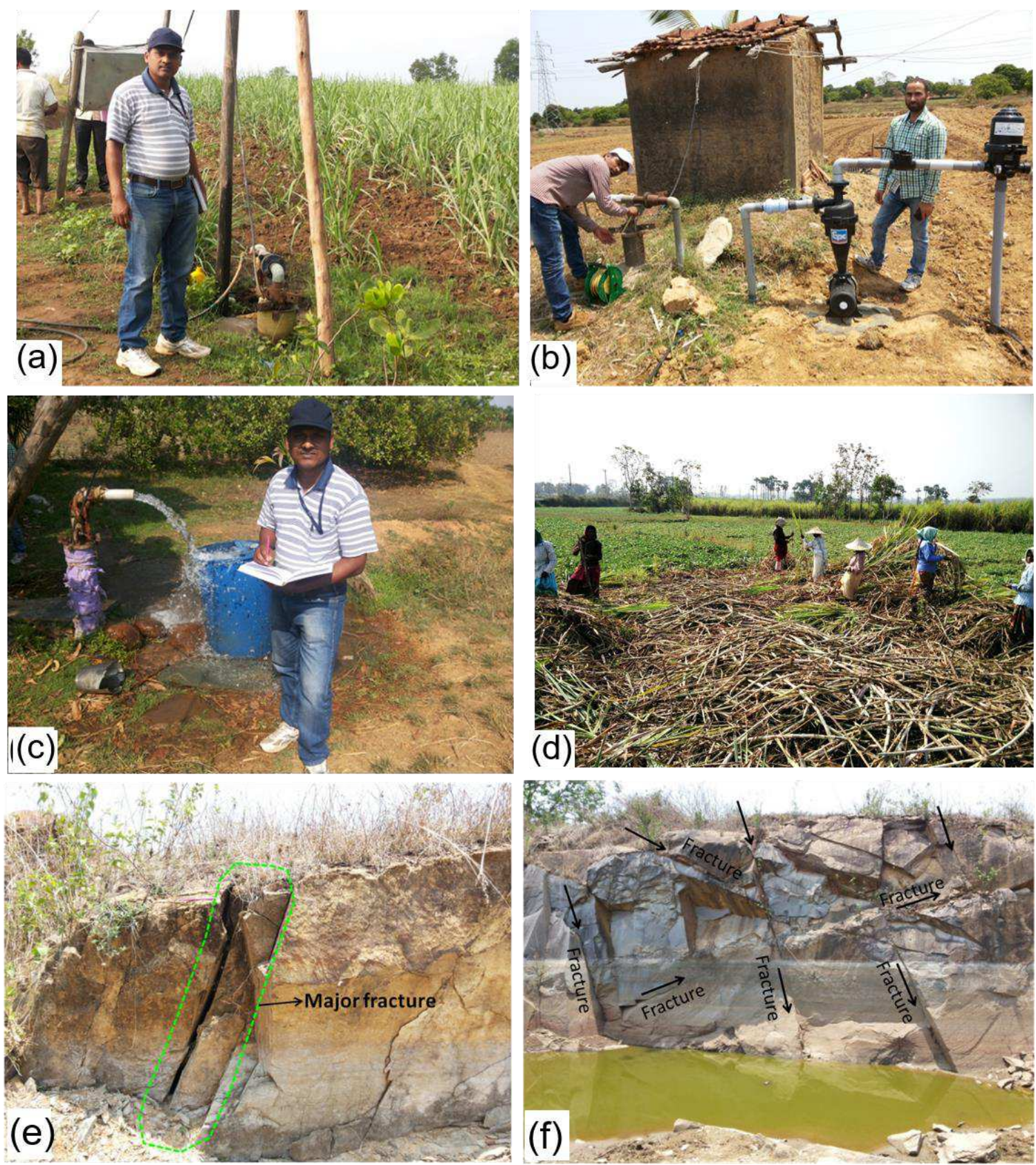

Fig. 3 Field snaps showing (a) sugarcane farm land, (b) deep bore well as irrigation source, (c) groundwater discharge, (d) sugarcane harvesting, (e) \& (f) fractures in the out crops of the hard rock. Theses fractures serve as potential recharge sites for groundwater.

\subsubsection{Groundwater recharge}

Groundwater recharge from the rainfall has been estimated on the groundwater resource estimation committee recommendation (GEC 1997). Recharge has been considered 12\% of the total rainfall in the hard rock aquifers. Most of the rainfall (>90\%) arrives in the monsoon period, therefore the recharge from rainfall is almost nil in non-monsoon (dry) period. Annual rainfall at Haliyal station varied from 868 to $1377 \mathrm{~mm}$ with an average annual 
rainfall of $1188 \mathrm{~mm}$ in the span of last decade (2007-17). Recharge from the irrigation return flow (IRF) is also computed using a relation shown in Eq. 1

$I R F=Q\left(C_{f}\right) \quad$ Eq. 1

where $\mathrm{Q}$ is groundwater abstraction and $\mathrm{C}_{\mathrm{f}}$ is return flow coefficient. The return flow coefficient is dependent upon several factors including soil texture \& type, types of crop, depth to water table and method of application. It varies widely (0.15-0.45) for the prevailing three major cropping patterns in the study area, i.e, Rabi, Kharif and Zaid (Umar \& Khan 2009). Return flow coefficient value is used $0.15<\mathrm{C}_{\mathrm{f}}<0.45$ based on the groundwater resource estimation committee (GEC 1997) for non-paddy crops.

\subsubsection{Aquifer Parameters}

The effective groundwater management practice requires a reliable aquifer property such as specific yield and other hydrogeological information (Freeze \& Cherry 1979). The hydraulic conductivity (K) has been assigned according to Domenico \& Schwartz (1990) for hard rock aquifers as $3 \times 10^{-6}$ to $5 \times 10^{-5}$ for weathered layer \& 8x10-

${ }^{9}$ to $3 \mathrm{E}-04$ for fractured layer. Another important aquifer property, specific yield (Sy; 2 to $8 \%$ ) was assigned into the entire aquifer, using data derived from previous studies (Marechal et al. 2004; Dewandel et al. 2010; Mizan et al. 2019 a \& b). Approximate property values for the aquifer layers have been considered from literature and latterly, it has calibrated in the model.

\subsubsection{Well discharge}

Well discharge rate changes with time according to the requirement of sugarcane and other crops. April to July is the most consumable period of the groundwater $\left(864 \mathrm{~m}^{3} /\right.$ day) followed by December to March ( $\left.576 \mathrm{~m}^{3} / \mathrm{day}\right)$ and August to November (288 $\mathrm{m}^{3} / \mathrm{day}$ ) (Fig. 3c). The pumping scheme information has been collected from the farmers. More than thousands (>1000) pumping borewells are uniformly distributed within the watershed.

\subsection{Electrical resistivity tomography (ERT) deriving aquifer geometry}

Electrical resistivity tomography (ERT) is an advanced tool which is widely applied to decipher the shallow subsurface (Stummer et al. 2004) on lateral and vertical scale (2D \& 3D) (Uhlemann et al. 2017) using multielectrodes. The theory and practical application and interpretation techniques of ERT are well described in the literature (Griffith et al. 1990; Barker 1981; Dahlin 1993; Griffith and Barker 1993; Loke and Barker 1996a 1996b; Loke 2001; Dahlin and Zhou 2004). The software program RES2DMOD developed by Loke (1999) was used to calculate the apparent resistivity using the finite difference method. A resistivity meter (ABEM Terrameter LS, Sweden make) was employed in the present case with 41-81 electrodes connected to the meter through a multicore cable having unit electrode spacing of 10 meters. The software known as RES2DINV (Loke 1994, 2001) is used to prepare the 'Inverse Model Resistivity Sections (IMRS)' and the Iteration RMS (route mean square) error was observed to be below 10\%. A total of 13 ERT profiles were carried out at different locations (Fig. 1 and Table 1) within the watershed covering flood plain, pediplain and pediments zones so that to generate a reliable hydrogeological model. The gradient configuration was used to acquire the resistivity data with maximum $A B$ spacing varies from $400 \mathrm{~m}$ to $800 \mathrm{~m}$ (depending on the space availability at sites) with maximum depth of investigations range 74-130 m (Table 1). The IMRS were demarcated with hydro-litho units for delineating the 
aquifer geometry. The aquifer geometric parameters derived from the ERT were fed to the numerical modelling for revealing the aquifer dynamics.

Table 1: Detailed information of ERT survey in the study area

\begin{tabular}{|l|l|l|l|l|l|l|}
\hline $\begin{array}{l}\text { Longitude } \\
(\text { Decimal } \\
\text { degree })\end{array}$ & $\begin{array}{l}\text { Latitude } \\
\text { (Decimal } \\
\text { degree) }\end{array}$ & ERT ID & Village & Array & $\begin{array}{l}\text { AB } \\
\text { spacing } \\
\text { (meters) }\end{array}$ & $\begin{array}{l}\text { Depth } \\
\text { investigation } \\
(\text { meters })\end{array}$ \\
\hline 74.85143 & 15.31416 & ERT-1 & Gadiyal & Gradient & 400 & 74 \\
\hline 74.73473 & 15.32999 & ERT-2 & Baloga & Gradient & 400 & 74 \\
\hline 74.72607 & 15.34328 & ERT-3 & Bidrolli & Gradient & 400 & 74 \\
\hline 74.83035 & 15.32639 & ERT-4 & Tatwangi & Gradient & 400 & 74 \\
\hline 74.74436 & 15.39414 & ERT-5 & Madanalli & Gradient & 400 & 74 \\
\hline 74.73869 & 15.4055 & ERT-6 & Aralwadi & Gradient & 400 & 74 \\
\hline 74.8349 & 15.20851 & ERT-7 & Jatage Hosur & Gradient & 800 & 130 \\
\hline 74.79266 & 15.2742 & ERT-8 & Malwadi & Gradient & 400 & 74 \\
\hline 74.89896 & 15.27566 & ERT-9 & Guledikoppa & Gradient & 400 & 74 \\
\hline 74.84921 & 15.25018 & ERT-10 & Belvatgi & Gradient & 400 & 74 \\
\hline 74.8194 & 15.26112 & ERT-11 & Mugodikoppa & Gradient & 400 & 74 \\
\hline 74.76909 & 15.31594 & ERT-12 & Haliyal & Gradient & 400 & 74 \\
\hline 74.77855 & 15.25485 & ERT-13 & Gundolli & Gradient & 800 & 130 \\
\hline
\end{tabular}

\subsection{Numerical modelling}

Numerical flow modelling of groundwater is widely applied for the estimation of aquifer dynamics (Surinaidu et al. 2013). Of the numerical modelling software, Visual Modular Three-Dimensional Flow (visual MODFLOW) based on 3D-finite difference method is widely applied for groundwater modelling (Annan 2000). The present study was run on visual MODFLOW 2000/2005 beginning with April 2015, in transient state with grid size 2000 m x 2000 m. Pumping scheme has been decided after various field studies. An averaged pumping scheme for the whole area with variation in hours of pumping depending on the season has been designed. The two layers, as layer 1 and layer 2 with $30 \mathrm{~m}$ and $20 \mathrm{~m}$ thick, respectively, derived from ERTs were considered. Theses layers were reference to the topographic elevation generated by DEM for the entire study area (Fig. 2a). These aquifer values have been used to run the model which upon calibration resulted in a model that matches the aquifer systems of Tattihalla River watershed. A calibrated model with 4 stress periods was run for 2 years for estimating the groundwater budget.

\subsection{Developing the DST}

The tool is based on the simple groundwater budget equation and water table fluctuation method (WTF) with the integration of numerical model. In this approach, it is aimed to integrate the numerical model with the tool to deal with determination of decisive scale for groundwater resource management and evaluate the groundwater budget components like groundwater abstraction, recharge, irrigation return flow, horizontal fluxes ( $\mathrm{q}_{\text {in }} \&$ qout) etc. 
Evaluated groundwater budget components at decisive cell scale have been imported into the tool which is based on Eqs. 1 to 5 for the generation of realistic scenario of future water level condition. The groundwater budget equation (Schicht and Walton 1961) is given in Eq. 2

$R+I R F+q_{\text {in }}=E+Q+q_{\text {out }}+q_{b f}+\Delta S \quad$ Eq.2

where $\mathrm{R}$ is groundwater recharge; IRF is the irrigation return flow; $\mathrm{q}_{\text {in }}$ and $\mathrm{q}_{\text {out }}$ are groundwater flows onto and off the system, E is evaporation, Q is the abstraction of groundwater by pumping, $\mathrm{q}_{\mathrm{bf}}$ is base flow (groundwater discharge to streams or springs) and $\Delta \mathrm{S}$ is change in groundwater storage. There is no perennial river present in the watershed, thus base flow ( $\mathrm{q}_{\mathrm{bf}}$ ) will be zero. Therefore, Eq. 3 can be rewritten as;

$\Delta S=R+I R F-Q+q_{\text {in }}-q_{\text {out }}-E \quad$ Eq. 3

The method determines the unknown storage of groundwater is the water table fluctuation method shown in Eq. 4 is,

$\Delta S=S_{y}(\Delta h) \quad$ Eq. 4

where $S_{y}$ is called the specific yield (storage) or the fillable porosity of the unconfined aquifer. Several authors (Kayane 1983; Sokolov and Chapman 1974; Sophocleous 1991) distinguish the terms "specific yield" and "fillable porosity". The term specific yield is most often used in connection with unconfined aquifers and is also known as the storage coefficient in case of confined aquifers. $\Delta \mathrm{h}$ is the change in water level between two seasons.

The two main budget components i.e. groundwater abstraction and recharge were considered as dynamic parameter owing to their high variability on time scale, while all other components were taking as constant throughout the time for the projections of water level. The computation of projected water level $h_{t+1}$, at time $t+1$, that of the next season, can be written as shown in Eq. 5

$h_{t+1}=h_{t}+\Delta h$

Eq. 5

The Eq. 5 can be modified using Eq. 4 as shown below

$h_{t+1}=h_{t}+\Delta S / S_{y} \quad$ Eq. 6

Where, $\mathrm{h}_{\mathrm{t}}$ is the water level at time $\mathrm{t}$ (last season). Eq. 3 has been used for the computation of $\Delta \mathrm{S}$ with changing R \& Q (considered dynamic components for the generation of scenarios).

\section{Results}

\subsection{Hydrogeological investigations}

The periodic monitoring of depth to water level from the 31 observation wells showed the alarming indications with gradual deepening of groundwater head during 2015-2017 (Fig. 4a-d). The depth to water level was recorded with wide range 1-49 m, bgl conveying the isolated and dynamic nature of the aquifer systems on spatio-temporal scale. During pre-monsoon 2015, more than $75 \%$ area was observed with the water level at 1-10 m depth range in the north west and south eastern part whereas, a small patch at the central part shows deeper water level $>10$ m, bgl (fig. 4a). However, with time, the continuous drought (2015-2017) and intense groundwater irrigation practices have resulted the deepening of the water level below $10 \mathrm{~m}$ depth reaching the hard rock (up to $50 \mathrm{~m}$ 
depth) in the central part (fig. 4b-c). It suggests to adapt a cell level decision support tool to check further spread of groundwater critical zones.

(a)

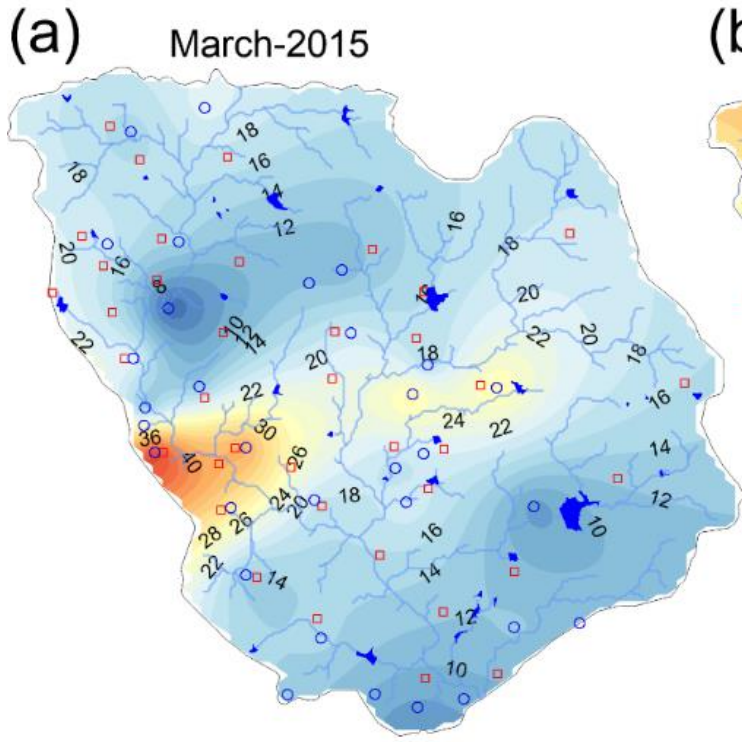

(c)

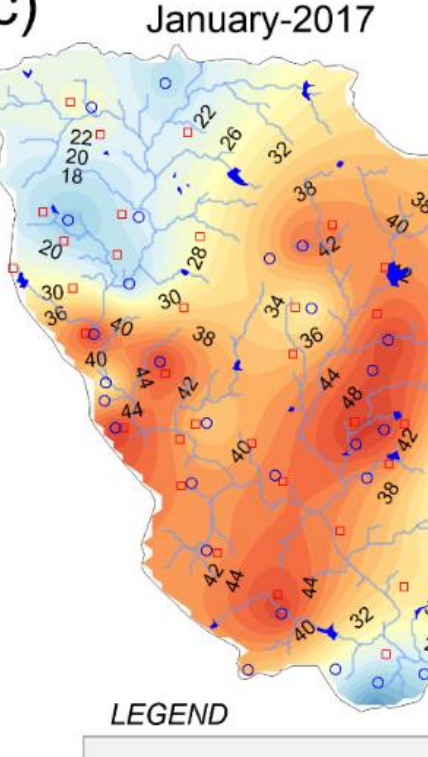

LEGEND (b)

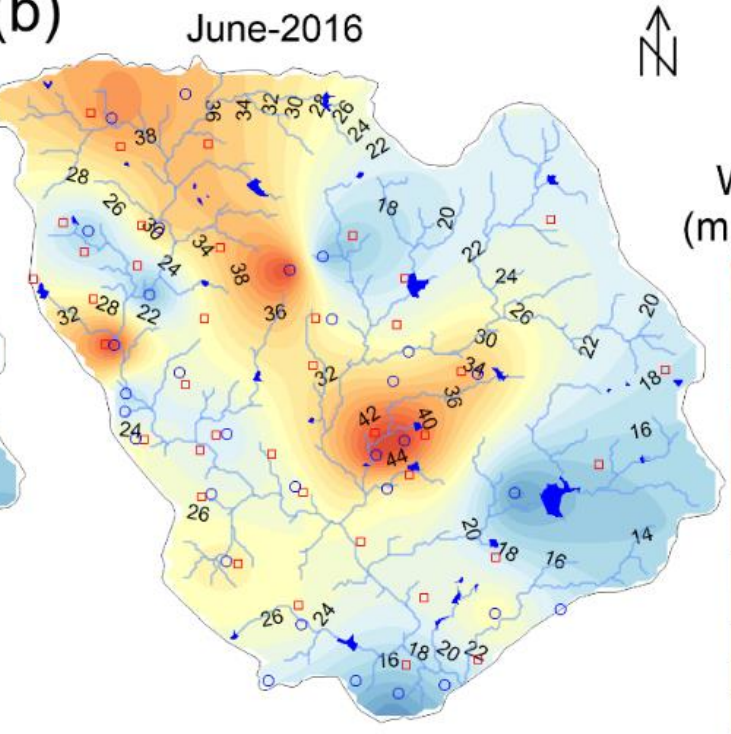

WL

(m, bgl)

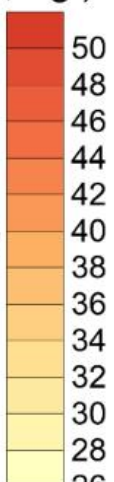

(d)

June-2017

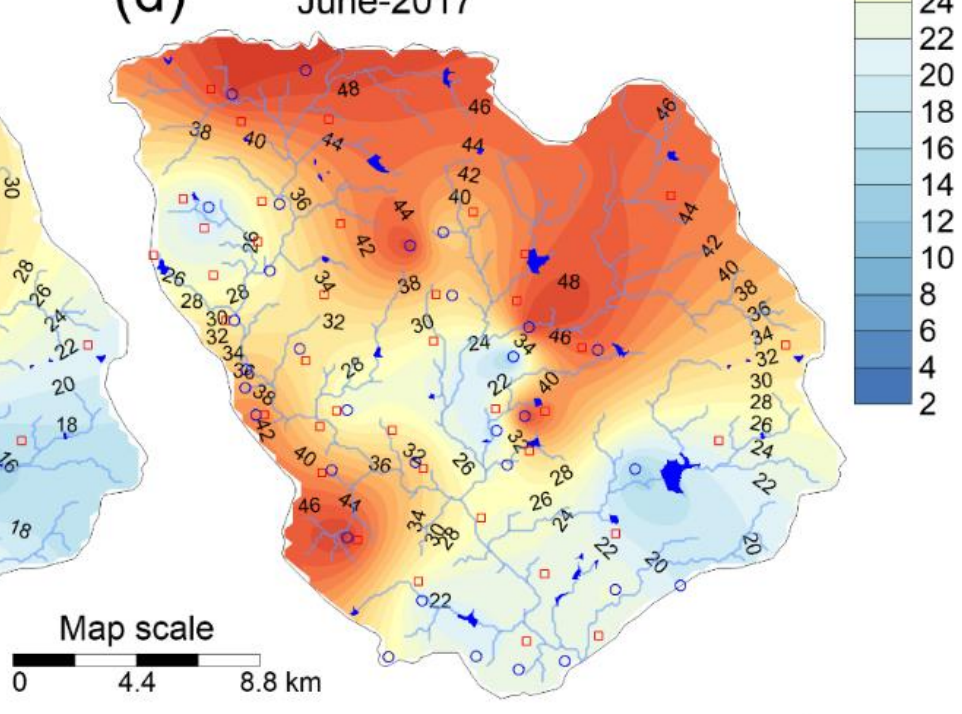

Tanks

Villages

Fig. 4 Contour map showing the water level (m, bgl) of (a) pre-monsoon-2015 (b) pre-monsoon 2016, (c) postmonsoon 2017, and (d) pre-monsoon 2017 in the study area.

\subsection{Aquifer geometric parameters}

The ERT-11 was carried out at Mugodikoppa village using gradient array with AB spacing $400 \mathrm{~m}$ (Table 1 and Fig. 5a). The survey point was characterized with flat topography (gentle slope), clayey soil of whitish yellow in colour, ploughed land, step like farming beset over Chlorite schist rocks. The zone belongs to groundwater over exploited area with mixed crops of sugar cane, sorgam and pulses. The resistivity image shows top soil followed by weathered (20-400 $\Omega \mathrm{m})$ up to about $27 \mathrm{~m}$ depth followed by saturated fractured zone with resistivity range 
400-1000 $\Omega \mathrm{m}$ extends up to about $50 \mathrm{~m}$ depth (Fig. 5a) below which hard rock ( $>4000 \Omega \mathrm{m})$ encounters. It confirms the zone belonging to groundwater potential under confined conditions.
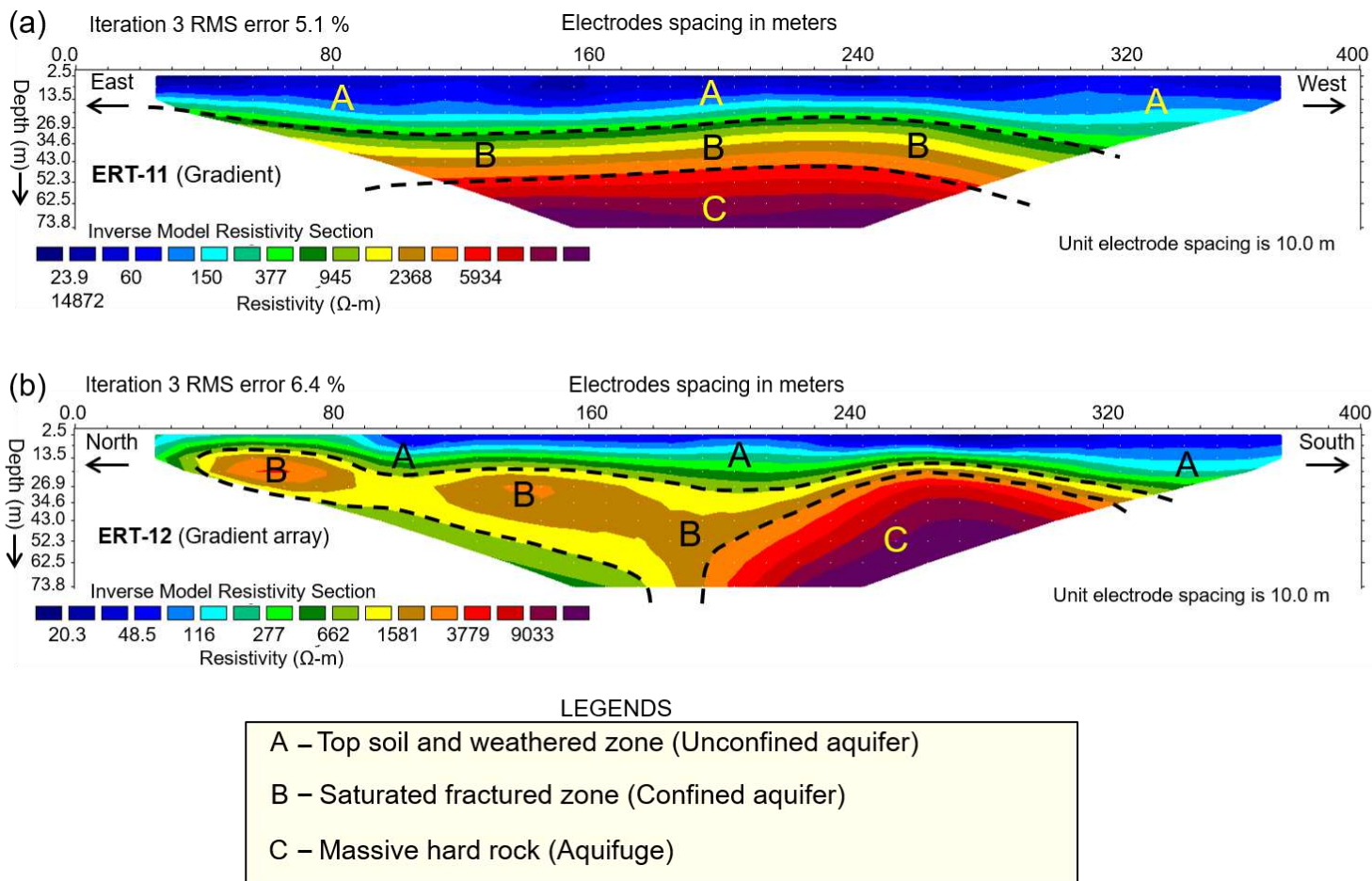

Fig. 5 Inverse model resistivity sections (IMRS) of the ERTs with hydro-lithological information from (a) Mugodikoppa village (ERT-11), and (b) Haliyal village (ERT-12) in the study area

The ERT-12 was carried out at Haliyal village using gradient array with AB spacing $400 \mathrm{~m}$ (Table 1 and Fig. 5b). The survey area was designated with flat to undulating topography, clayey soil with whitish to grey colour, post harvested sugar cane land, pediplain area situated over Chlorite schist rock. Hydrogeologically, the aquifer systems are under confined conditions of fractured zone. The resistivity image shows the regolith thickness with top soil and weathered zone (20-500 $\Omega \mathrm{m})$ up to 13-26 m depth followed by saturated fractured layer (500-2000 $\Omega \mathrm{m}$ ) for varying depth up to $60 \mathrm{~m}$. The shallow hard rock (>2000 $\Omega \mathrm{m}$ ) with varying depth $20-60 \mathrm{~m}$ was recorded in the middle to southern part of the profile (Fig. 4b). The area shows potential groundwater sources under confined conditions in fractured layer. These aquifer parameters were accounted as an input to the groundwater numerical modelling.

\subsection{Groundwater model}

The aquifer system is 2 layered with 3-dimensional discretization of the flow model with varying aquifer depths (Fig. 6a-b). The thickness of vertical layers is referenced with topographic elevation which controls the hydraulic gradient (Fig. 6a-b). The boundaries act as no flow zones because of the closed watershed model as a single hydrogeological unit with spatial aquifer dynamics. Contour maps of hydraulic head referenced to mean sea level suggests the groundwater flow direction from north to south direction following the topographic slope (Fig. 2a). In pumping wells, the casing up to the weathered zone induces the water from the second layer of saturated fractured zone. This acts as screen generating a 3-dimensional flow. Groundwater follows the gradient and the 
specifics of modelling change in space and time. A transient model with recharge and water bodies as source, and evaporation / evapotranspiration and pumping wells as sinks was conceptualized in this study.
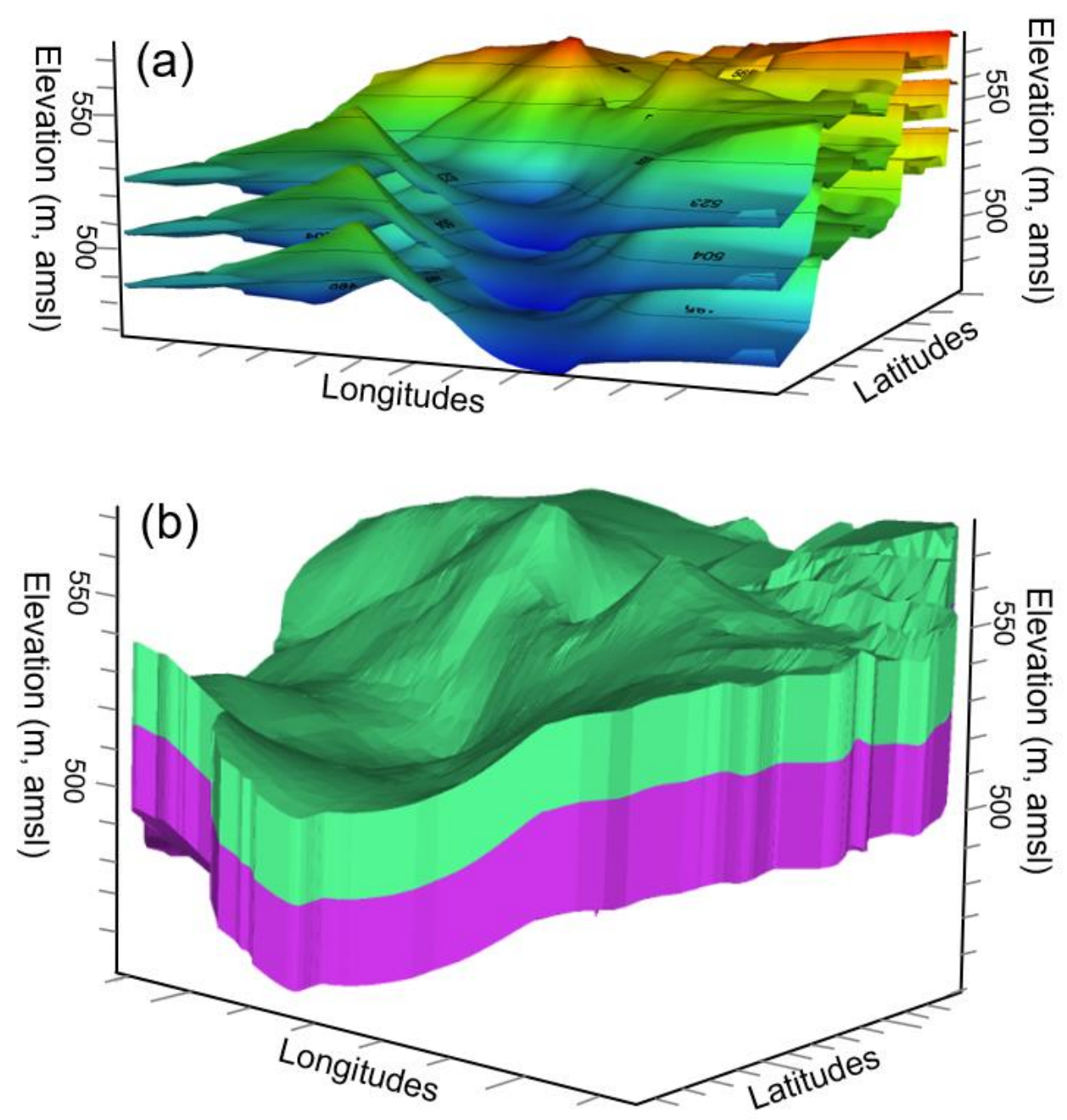

Fig. 6 Models showing (a) Layering system in the watershed, and (b) 3-dimensional discretization of the 2-layer model

\subsubsection{Model calibration and validation}

Calibration results of calculated vs. observed groundwater head show the sensitivity to hydraulic conductivity, specific yield and recharge. Parameters were calibrated and a flow model was run to match the water level values collected for four stress period during the field study. Thorough calibration was done for the model, a well estimated value shown in Tables $2 \& 3$ was considered. With an overall accuracy of 97\%, the model was developed using the existing field data which changes over course. The normalized RMS error for the calculated vs. observed groundwater head was recorded $7.57 \%$ indicating the robustness of the model (Fig. 7). This numerical modelling acts as an intermediary step for providing inputs to develop the DST for generation of water level projection scenarios. 
Table 2 Final hydraulic property values after calibration and validation.

\begin{tabular}{|c|c|c|c|c|c|}
\hline Property & \multicolumn{2}{|c|}{ Quartz - Chlorite Schist } & \multicolumn{2}{|c|}{ Banded Magnetite Quartzite } & Dolerite dyke \\
\hline & Layer 1 & Layer 2 & Layer 1 & Layer 2 & \\
\hline $\begin{array}{l}\text { Hydraulic conductivity } \\
(\mathrm{m} / \mathrm{d})\end{array}$ & $2 \times 10^{-2}$ & $6 \times 10^{-2}$ & $8 \times 10^{-2}$ & $1 \times 10^{-1}$ & \\
\hline Specific Storage $(1 / \mathrm{m})$ & 0.0002 & & & & $1 \times 10^{-11}$ \\
\hline Specific Yield (\%) & 0.1 & & & & \\
\hline Effective Porosity (\%) & 0.1 & & & & \\
\hline Total Porosity (\%) & 0.15 & & & & \\
\hline
\end{tabular}

Table 3 Recharge rates

\begin{tabular}{|l|l|}
\hline Days & Recharge $(\mathrm{m})$ \\
\hline $0-61$ & 0 \\
\hline $61-214$ & 1 \\
\hline $214-427$ & 0 \\
\hline $427-580$ & 0.78 \\
\hline $527-797$ & 0 \\
\hline
\end{tabular}

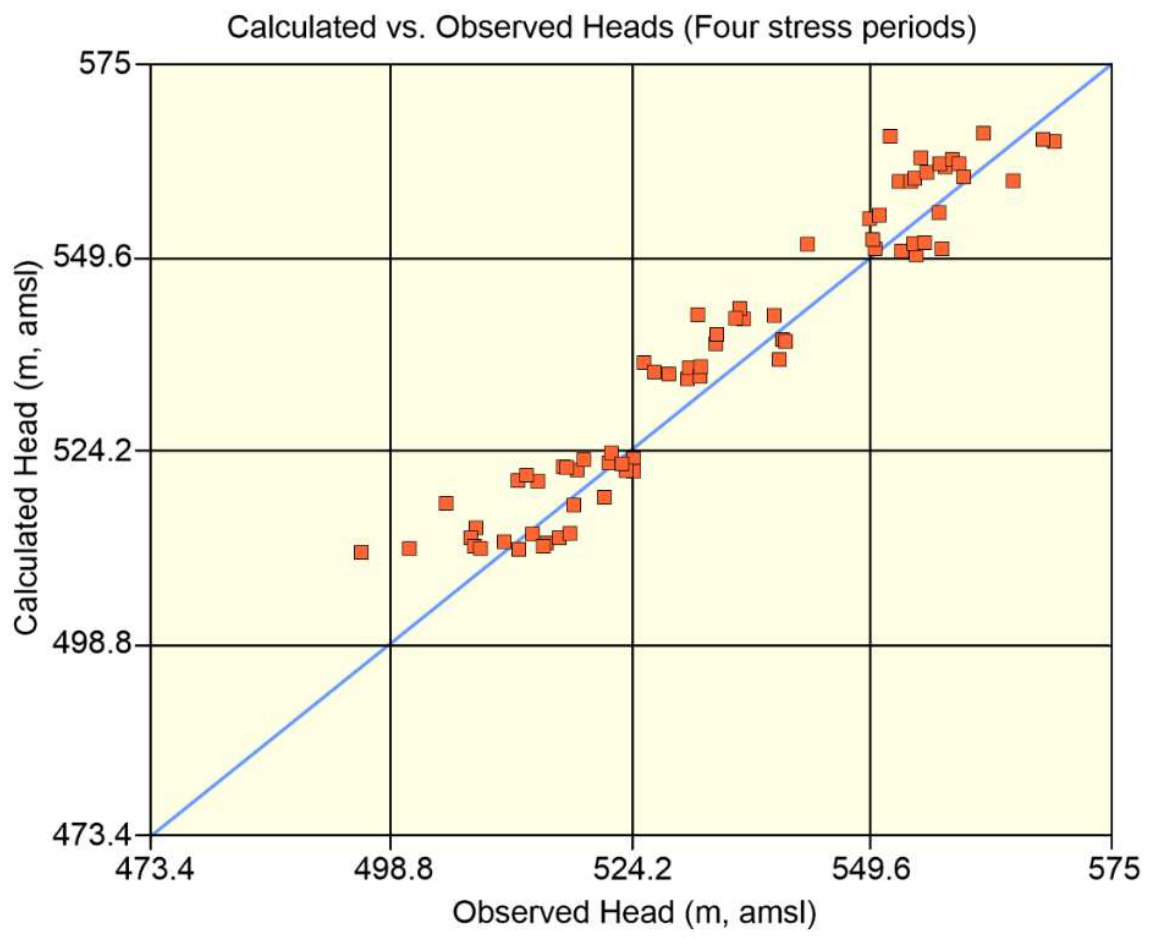

Min. Residual: $0.042(\mathrm{~m})$ at $014 / 14$ Time $=0$ Max. Residual: $15.39(\mathrm{~m})$ at $05 / 5$ Time $=797$ Residual Mean: $2.94(\mathrm{~m})$

Standarad Error of the Estimate: $0.54(\mathrm{~m})$

Root Mean Squared: $5.53(\mathrm{~m})$

Normalized RMS: 7.57 (\%)

Abs. Residual Mean: $4.63(\mathrm{~m})$

Correlation Coefficient: 0.97

Fig. 7 Calibration results with normalized RMS Error 7.57\% for four stress period. 
Further, to provide the cell level decisive support tool, the study area has been made into $2 \mathrm{~km} \times 2 \mathrm{~km}$ grids (cells) with their intrinsic aquifer properties (Fig. 8). Based on the sugarcane land use, a total of 77 grids were selected for groundwater management at cell scale in Tattihalla watershed (Fig. 8). The cell Nos. 12 and 60 marked on the Figure 8 are presented in this paper for projecting future water level scenarios with various pumping patterns.

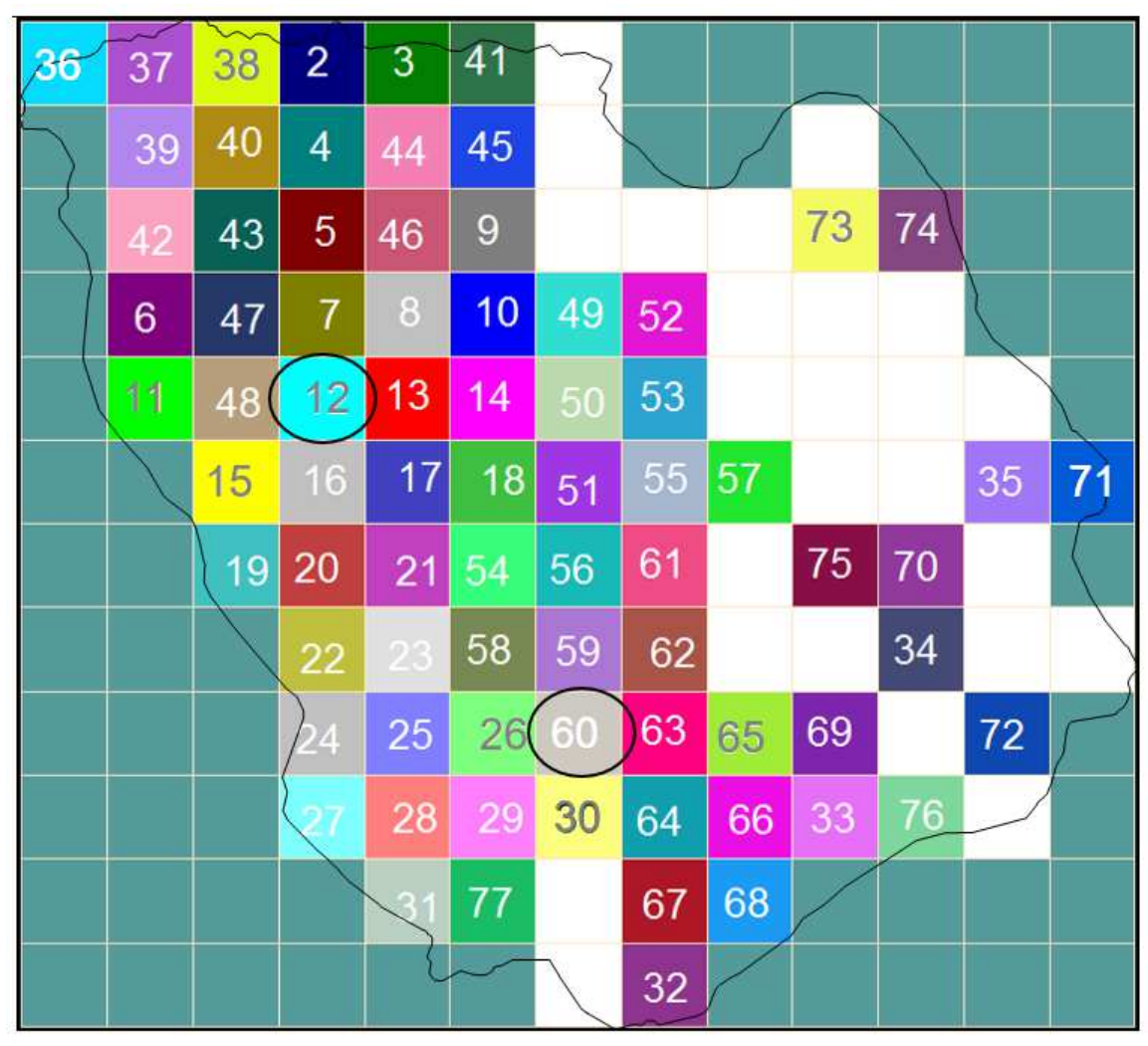

Fig. 8 Selected cells for groundwater management at $2 \mathrm{~km} \times 2 \mathrm{~km}$ scale in Tattihalla watershed based on the sugarcane land use. The cells 12 and 60 marked on the image are presented in this paper for projecting future water scenarios with various pumping patterns

\subsection{Decision support tool (DST)}

\subsubsection{Groundwater budget at cell scale}

On validation and calibration, these 77 sugarcane specific zones (cells) referred from LULC (Fig. 2b) were selected to estimate the groundwater budget with cell size of $2 \mathrm{~km} \times 2 \mathrm{~km}$. Of the 77, the cell Nos. $12 \& 60$ marked on Figure 8 have been taken for the detailed explanation in this paper based on the varying hydrogeological behaviour (Fig. 7). In view of the complex aquifer systems with devoid of local or regional hydraulic connections, the small-scale DST would promote the farm level groundwater management. The numerical model assists to select zone budget at cell scale that a user can also choose a cell of individual or village level for the sustainable groundwater management. After creating the cells, the groundwater budget components have been extracted from cell $12 \& 60$ and imported into developed DST for the generation of possible scenarios. These components are; recharge, groundwater abstraction, lateral in \& out fluxes, observed water level, and evaporation. Aquifer geometry and calibrated specific yield are also incorporated in the tool for the generation of possible scenario. Historical rainfall (10 years) has been considered in a cyclic repetition for future rainfall.

\subsubsection{Projection of water level}


Upon incorporation of all the groundwater budget components into the tool, the projection of water level was performed using different groundwater abstraction scenarios. The hydraulic model was linked with the historical rainfall values of the area for future projection of natural recharge. Natural recharge for future projection has been assigned $12 \%$ of historical rainfall according to groundwater estimation committee (GEC 1997). The scenario modules allow creating different theoretical scenarios to test the impact of different managements strategies on groundwater resources. Figure 9a-b shows the variations in projected water level under different groundwater abstraction rate for cells $12 \& 60$. In cell 12, the projected water level against the increased groundwater abstract of $10 \%, 25 \%$, and $50 \%$ indicate the declining trend (Fig. 9a). In Scenario 1, groundwater abstraction has been increased $10 \%$ in cumulative form for 10 years. The responded groundwater depletion was observed starting with time but yet to reach the basement of aquifer (Fig. 9a). In scenario 2, the $25 \%$ increased groundwater abstraction observes the intense depletion of water level tending toward the basement. In scenario 3, the $50 \%$ increase in groundwater abstraction rate resulted rapid declining of water level touching the basement (well goes dry) in 2025 (Fig. 9a).

In cell 60, the projected water level against the increased groundwater abstraction of $10 \%, 25 \%$, and $50 \%$ showed similar fashion like cell 12 with varying magnitude of time. In scenario 1 for $10 \%$ increase in groundwater abstraction rate, the projected water level trend showed poor declining trend. In scenario 2, the depletion of water level has started but it was not much significant in comparison with cell 12 against $20 \%$ increase in groundwater pumping. After that, scenario 3 for $50 \%$ increase in groundwater pumping, records some abrupt depletion trend of water level but it was not drying the aquifer in projected 10 years of period (Fig. 9b). Overall, in comparison with cell 12, the cell 60 shows the declining trend of water level for scenario $2 \& 3$ but with drastic variation in magnitude of depletion.

Similarly, water level of all the 77 cells have been projected against 10\%, 25\% and $50 \%$ increased pumping rates to evaluate the futuristic groundwater condition within the watershed (Fig. 10). Since each cell has different topographic elevation and aquifer basement, the aquifer is not discretized into the layers. With the increase of $10 \%$ groundwater abstraction rate, all the cells show almost similar trend of water level (Fig. 10a). While the trend of projected water level show abrupt changes in some cells with $25 \%$ and $50 \%$ abstraction rate (Fig. 10b-c). These abrupt water level behavioural changes are observed with accelerated declining trend against 50\% increased abstraction rate (Fig. 10c). It suggests the insignificant effect of $10 \%$ increased pumping rate on the groundwater level as compared to $25 \%$ \& $50 \%$ increased pumping rates. Over all, it implies that the variation in aquifer behaviour on spatial scale suggest to opt cell level decision instead of watershed level or large scale. Further, it was observed that each cell has individual consumption of groundwater for irrigation purpose where the higher groundwater abstracted cells showed more depletion of groundwater with $25 \%$ and $50 \%$ pumping scenarios (Fig. $10 \mathrm{~b}-\mathrm{c})$. Projection of water level for all the cells (77) provides the complete picture of groundwater resource condition in the next decade which would be very helpful for policymakers to prepare the plans to tackle the worst scenarios. 

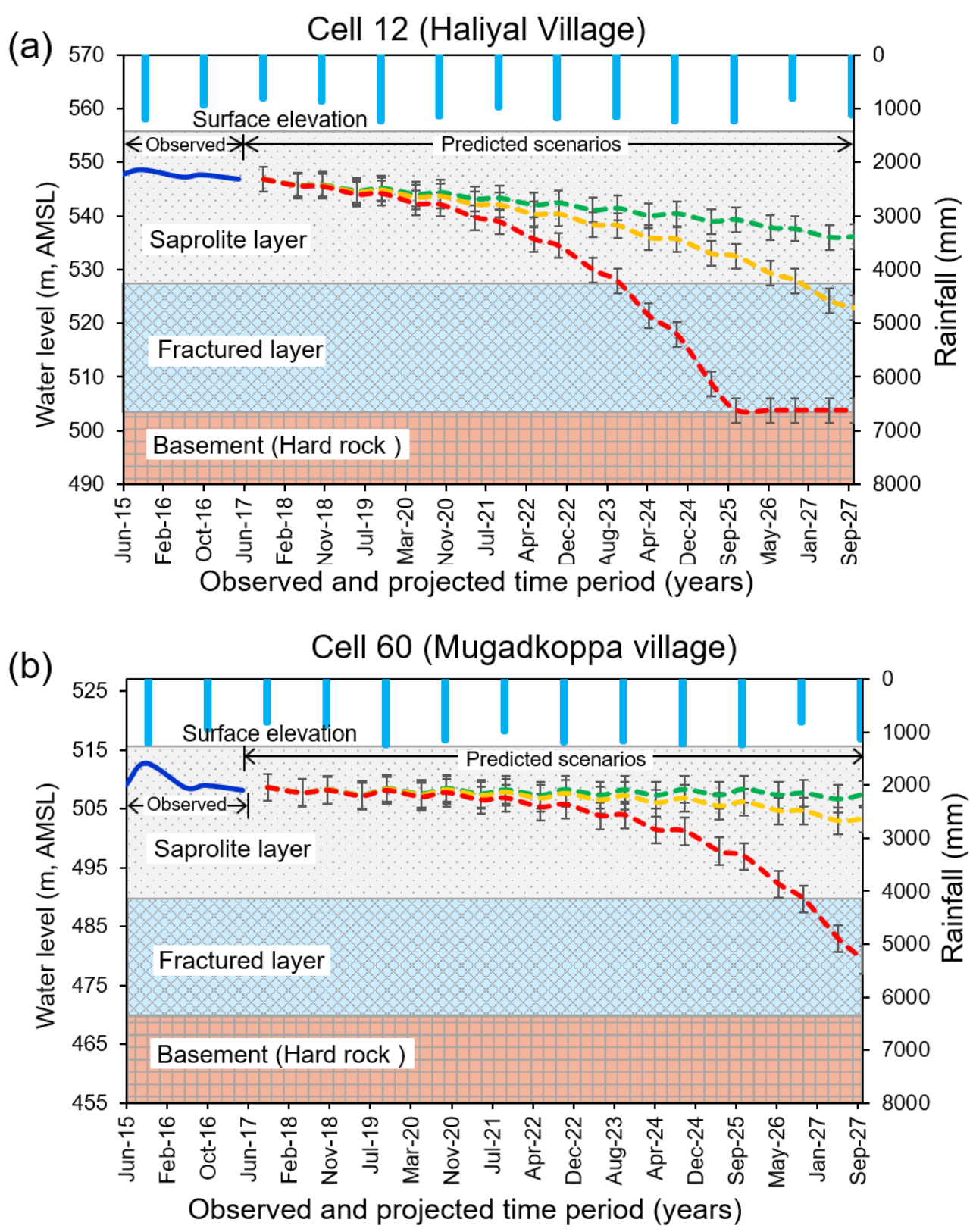

LEGENDS

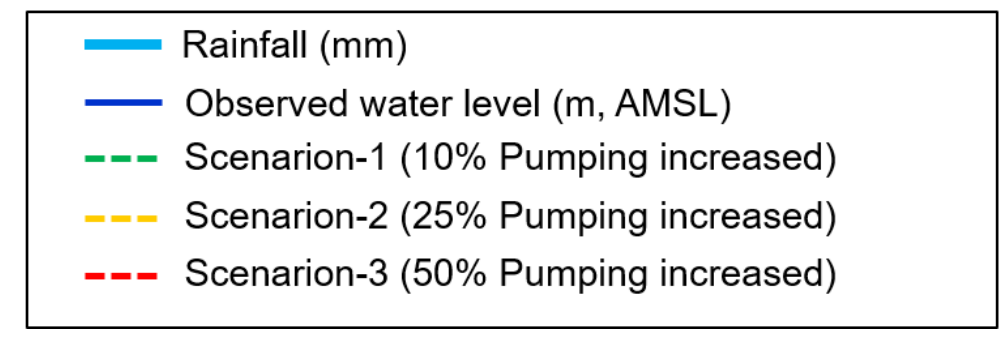

Fig. 9 Projection of future water level with 10\%, 20\% \& 30\% increased pumping rates at (a) cell-12 (Haliyal village), and (b) cell-60 (Mugodikoppa village). 

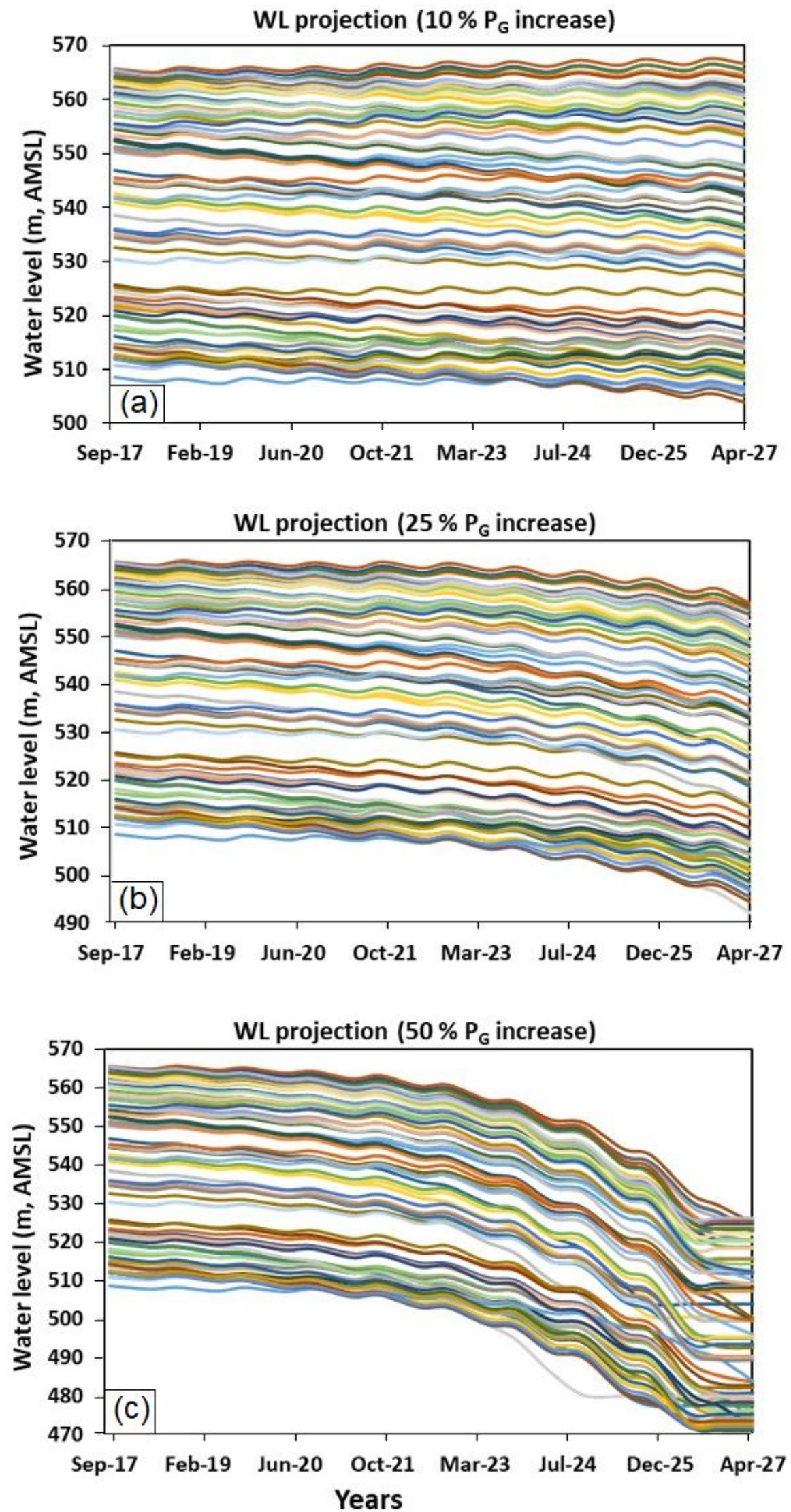

Fig. 10 Projection of future water level at all the 76 cells with increased pumping rates of (a) $10 \%$, (b) $20 \%$, and (c) $30 \%$ 


\section{Discussion}

DST has been developed specially to test the impact of changing groundwater abstraction rate on groundwater levels at cell scale in the sugarcane agriculture dominant areas. The DST employed water level projections brings new insight to improve the groundwater management strategies. The information generated from DST can guide farmers or crop planner to plan for efficient and sustainable ground water management for sugarcane crops and also spot the water scarcity due to high groundwater consumption.

The water level scenarios have been created according to the groundwater abstraction rate. The result shows severe depletion of water level in some area of the watershed in the upcoming decade. For the detailed explanation, the projection of water level particularly for two cells $(12 \& 60)$ (Fig. 9a-b) are presented to demonstrate the importance groundwater management at cell scale. The basement (hard rock) depth in cell 12 is at $~ 50 \mathrm{~m}$ depth, whereas in cell 60 it is encountered at $46 \mathrm{~m}$ depth indicating more scope for the aquifer system in cell 12 (Fig. 9ab). But in contrary, the cell 12 has been found more vulnerable to drought conditions due to the dominancy of sugarcane farms as recorded form LULC (Fig. 2b). It advocates, each cell requires to manage distinctively based on its availability of groundwater resources, and the same prescription of groundwater management strategies may not work across the cells. In case of cell 60 , availability of water resource for irrigation of sugarcane crops would not adverse under three scenarios although the trendline of water level showing the declination i.e, it can reach aquifer basement beyond 10 years period. Cell 60 may sustain groundwater as an irrigation source for longer duration of sugarcane crop subject to practice the developed DST recommendations. It may increase the area of land use (sugarcane crop) in alternate years (i.e, in one-year farmers can conserve the water and next year they can use it for more sugarcane production).

Further, the projected water levels in the entire watershed predicts the upcoming alarming conditions in the sugarcane dominated cells. The groundwater resources are limited at cell as well as watershed scale, therefore further neglection may have adverse impact on sugarcane farmers resulting the drastic decline in sugarcane crops in the next decade due to water scarcity in the water stressed cells. The overall groundwater level simulation suggest that the sugarcane agricultural economy would suffer potentially in the next decade if failed to take appropriate measures in the study area. Water stewardship will envisage water actors in the watershed to make long term action plan for water security. Further ground water security could be achieved through maximizing the use of surface water (Perin et al. 2012), preservation of water resource through artificial recharge structures (Boisson et al. 2014), precision-based irrigation system, and efficient soil water management.

\section{Conclusions}

A refined hydrogeological conceptual model based on geophysical data and hydraulic parameters of the watershed is incorporated to perform the numerical modelling and developed the DST in sugarcane farming areas of Tattihalla watershed Uttar Kannada District, Karnataka State, India. Model has been run into the transient mode for four stress periods during 2015-2017. The validation of calculated and observed heads with RMS error 7.57\% shows its robustness estimating the groundwater budget at $2 \mathrm{~km} \times 2 \mathrm{~km}$ cell scale at 77 cells in the sugarcane dominated areas. The evaluated groundwater budget components are linked to the developed DST keeping the recharge and groundwater abstraction as a variable component for the generation of theoretical scenarios. These scenarios have been created for the projection of water level for the next 10 years. 
The specific cases at cell 12 and 60 shows similar pattern of water level against the increased groundwater abstraction rates of $10 \%, 25 \%$, and $50 \%$. However, the temporal magnitude of water level suggests drastic variations among these two cells which decide their ability to cope up with drought conditions. The cell 12, despite having greater aquifer scope, is observed to be more vulnerable to drought due to dominancy of sugarcane farms and sensitive aquifer dynamics. With 50\% increased groundwater pumping rates the cell 12 touches basement resulting dry bore well in September 2025, whereas cell 60 continuous to yield groundwater beyond the year 2025. The scenarios generated results across the cells (77 cells) decipher the isolated aquifer systems with varying dynamics behaviour. It advocates to adapt small scale decision support tools at farm level or village level for achieving the concept of sustainable groundwater management.

\section{Acknowledgements:}

This study was funded by World Wide Fund for Nature-India (WWF-India). We are thankful to the EID Parry Sugar Mill, Haliyal authority for providing the logistic support and their cooperation during the field work including hydrogeological and geophysical investigations. We acknowledge Dr. Shakeel Ahmed (CSIR-NGRI) for his administrative support to the project. Dr. E. Nagaiah (CSIR-NGRI) and Dr. Farooq Ahmed Dar (University of Kashmir) supported during the field work. We thank to Dr. V.M. Tiwari, Director CSIR-NGRI Hyderabad for his encouragement and approving (Ref. No. NGRI/Lib/2020/ Pub-226) the paper for publication.

\section{References}

Anon (2000) SSG software. The Scientific Software Group, Washington. http://www.scisoftware.com

Barker R (1981) The offset system of electrical resistivity sounding and its use with a multicore cable. Geophys Prospect 29: 128-143.

Bordonal RdO, Carvalho JLN, Lal R, et al. (2018) Sustainability of sugarcane production in Brazil. A review. Agron. Sustain. Dev. 38, 13 (2018). https://doi.org/10.1007/s13593-018-0490-X

CGWB (2007) Dynamic Ground Water Resources of India. Central Ground Water Board, Ministry of Water Resources, Government of India, Faridabad

Chadwick B, Ramakrishnan M, Viswanatha MN (1981) The stratigraphy and structure of the Chitradurga region: an illustration of cover-basement interaction in the late Archaean evolution of the Karnataka craton, southern India. Precambrian Research, 16(1-2), 31-54.

Chadwick B, Vasudev VN, Hegdet GV (1997) The Dharwar craton, southern India, and its Late Archaean plate tectonic setting: current interpretations and controversies. Proc. Indian Acad. Sci. (Earth Planet. Sci.), 106, No. 4, December 1997, pp. 249-258

Chandra S, Auken E, Maurya PK, Ahmed S, Verma SK (2019) Large scale mapping of fractures and groundwater pathways in crystalline hardrock by AEM: Scientific Reports, 9, 398, doi: 10.1038/s41598-018-36153-1.

Chilton PJ, Foster SSD (1995. Hydrogeological characterisation and water-supply potential of basement aquifers in tropical Africa. Hydrogeology journal, 3(1), 36-49.

Courtois N, Lachassagne P, Wyns R, Blanchin R, Bougaïré FD, Somé S, Tapsoba A (2010) Large-scale mapping of hard-rock aquifer properties applied to Burkina Faso. Groundwater, 48(2), 269-283. 
Courtois N, Lachassagne P, Wyns R, Blanchin R, Some S, Tapsoba A, Bougaïre FD (2008) Experimental GIS hydrogeological mapping of hard-rock aquifers in Burkina Faso, to help for groundwater management and planning. In Poster at International Conference 'Groundwater and Climate in Africa', Kampala, Uganda.

Dahlin T (1993) On the automation of 2D resistivity surveying for engineering and environmental applications. PhD Thesis. Deparment of Engineering Geology, Lund Institute of Technology, Lund University, Sweden. ISRN: LUTVDG/TVTG1007SE. ISBN 9162810324. 187 pp.

Dahlin T, Zhou B (2004) A numerical comparison of 2D resistivity imaging with 10 electrode arrays. Geophysical Prospecting, 52 (5), 379-398.

Dewandel B, Lachassagne P, Wyns R, Maréchal JC, Krishnamurthy NS (2006) A generalized 3-D geological and hydrogeological conceptual model of granite aquifers controlled by single or multiphase weathering. Journal of hydrology, 330(1-2), 260-284.

Dewandel B, Maréchal JC, Bour O, Ladouche B, Ahmed S, Chandra S, Pauwels H (2012) Upscaling and regionalizing hydraulic conductivity and effective porosity at watershed scale in deeply weathered crystalline aquifers. Journal of Hydrology, 416, 83-97.

Dewandel B, Perrin J, Ahmed S, Aulong S, Hrkal Z, Lachassagne P, et al. (2010) Development of a tool for managing groundwater resources in semi-arid hard rock regions: application to a rural watershed in South India. Hydrological Processes, 24(19), 2784-2797.

Dhawan V (2017) Water and Agriculture in India. Background paper for the South Asia expert panel during the Global Forum for Food and Agriculture (GFFA). Pp.1

Domenico PA, Schwartz FW (1990) Physical and Chemical Hydrogeology, John Wiley \& Sons, New York, 824

Fishman R (2018) Groundwater depletion limits the scope for adaptation to increased rainfall variability in India. Climatic Change,147, 195-209.

Freeze RA, Cherry JA (1979) Groundwater. Prentice-Hall.

GEC (Groundwater Estimation Committee) (1997) Groundwater resource estimation methodology. Report of Ministry of Water Resources, New Delhi, India.

Grriffth DH, Barker RD (1993) Two dimensional imaging modeling in areas of complex geology. Journal of Applied Geophysics Vol.20, pp 211-226

Griffth DH, Turnbull J, Olayinka AI (1990) Two dimensional resistivity mapping with a computer controlled array. First Break, Vol.8, pp 121-129

Howard KWF (2014) Sustainable cities and the groundwater governance challenge. Environ Earth Sci. doi:10.1007/s12665-014-3370-y

Jamieson DG (1997) Special Issue on decision-support systems (DSS). J Hydrol 199:211-212

Janža MA (2015) Decision support system for emergency response to groundwater resource pollution in an urban area (Ljubljana, Slovenia). Environ Earth Sci 73, 3763-3774. https://doi.org/10.1007/s12665-014-3662-2

Krásný J, Sharp JM (2007) Hydrogeology of fractured rocks from particular fractures to regional approaches: state-of-the-art and future challenges. Groundwater of fractured rocks. Taylor and Francis, London, 1-32.

Kayane I (1983) Some problems relating to groundwater balance. Hydrolological Sci J, 28 (1) 125-137.

Loke MH (1994) The inversion of two-dimensional resistivity data. Unpubl. PhD thesis, Un. Of Birmingham.

Loke MH (1999) RES2DMOD Version 2.2: Rapid 2-D Resistivity Forward Modeling Using the Finite-difference and Finite-element Methods. Report GeoTomo LLC, Penang, Malaysia. 
Loke MH (2001. Electrical Imaging Surveys for Environmental and Engineering Studies. A Practical Guide to 2D and 3-D Surveys. RES2DINV Manual. IRIS Instruments. www.iris-intruments.com.

Loke MH, Barker RD (1996a. Rapid least squares inversion of apparent resistivity pseudosections by a quasi Newton method. Geophys Prospect 44: 131-152

Loke MH, Barker RD (1996b. Practical techniques for 3D resistivity surveys and data inversion. Geophys Prospect 44: 499-523

Maréchal JC, Dewandel B, Subrahmanyam K (2004) Use of hydraulic tests at different scales to characterize fracture network properties in the weathered-fractured layer of a hard rock aquifer. Water Resources Research, 40(11).

Maréchal JC, Dewandel B, Ahmed S, Lachassagne P (2007) Hard rock aquifers characterization prior to modelling at catchment scale: an application to India. Groundwater in fractured rocks, IAH Selected Papers, 9, 1-30.

Maréchal JC, Selles A, Dewandel B, Boisson A, Perrin J, Ahmed S (2018) An Observatory of Groundwater in Crystalline Rock Aquifers Exposed to a Changing Environment: Hyderabad, India

Maurya VP, Chandra S, Sonkamble S, Kumar KL, Nagaiah E, Selles A (2021. Electrically Inferred Subsurface Fractures in the Crystalline Hard Rocks of an Experimental Hydrogeological Park, Southern India. Geophysics 86(3), 1-10 https://doi.org/10.1190/geo2020-0327.1

Mizan SA, Ahmed S, Selles A (2019a) Spatial estimation of groundwater storage from a 2D specific yield in the crystalline aquifer of the Maheshwaram watershed. Journal of Earth System Science, 128(7), 1-10.

Mizan SA, Dewandel B, Selles A, Ahmed S, Caballero Y (2019b) A simple groundwater balance tool to evaluate the three-dimensional specific yield and the two-dimensional recharge: application to a deeply weathered crystalline aquifer in southern India. Hydrogeology Journal, 27(8), 3063-3080

Naik PK, Awahthi AK (2003) Groundwater resources assessment of the Koyna River basin, India. Hydrogeol J 11(5):582-594

Nath SJ, Ramakrishnan M, Viswanatha MN (1976) Dharwar stratigraphie model and Karnataka eraton evolution; Geol. Surv. India Records 107 149-175

National Research Council (1997) Valuing ground water: economic concepts and approaches. National Academy Press, Washington, DC, $189 \mathrm{p}$

Nicolas M, Bour O, Selles A, Dewandel B, et al. (2019) Managed Aquifer Recharge in fractured crystalline rock aquifers: Impact of horizontal preferential flow on recharge dynamics. J Hydrology, 573, 717-732

NITI Ayog (2020) Final report of the Task Force Sugarcane and Sugar Indiustry, 2020, NITI Ayog). https://niti.gov.in/node/1287

Omorinbola EO (1982) Verification of some geohydrological implications of deep weathering in the Basement Complex of Nigeria. Journal of Hydrology, 56(3-4), 347-368.

Omorinbola EO (1983) Shallow seismic investigation for location and evaluation of groundwater reserves in the weathered mantles of the Basement Complex in southwestern Nigeria. Geoexploration, 21(1), 73-86.

Owoade A (1995. The potential for minimizing drawdowns in groundwater wells in tropical aquifers. Journal of African Earth Sciences, 20(3-4), 289-293.

Pierce SA, Sharp JM, Eaton DJ (2016) Decision Support Systems and Processes for Groundwater. In Integrated Groundwater Management (pp. 639-665). Springer, Cham. 
Sarwar MA, Ibrahim M, Tahir M, Ahmad K, Khan ZI, Valeem EE (2010 Appraisal of press mud and inorganic fertilizers on soil properties, yield and sugarcane quality. Pak J Bot 42(2):1361-1367

Schicht RJ, Walton WC (1961. Hydrologic budgets for three small watersheds in

Illinois. Illinois state water survey, Report of investigation, 40, 40.

Shrivastava AK, Srivastava AK, Solomon S (2011. Sustaining sugarcane productivity under depleting water resources. Current Science 101(6):748-754

Sishodia RP, Shukla S, Graham, WD, Wani SP, Garg KK (2016) Bi-decadal groundwater level trends in a semiarid south indian region: Declines, causes and management. J Hydrology: Regional Studies 8, 43-58,

Sokolov AA, Chapman TG (1974) Methods for Water Balance Computations. UNESCO, Paris, pp 127.

Sophocleous MA (1991. Combining the soil water balance and water-level fluctuation methods to estimate natural ground water recharge: practical aspects. Journal of Hydrology, (124) 229-241.

Sonkamble S, Chandra S, Nagaiah E, Dar FA, Somvanshi VK, Ahmed S (2014) Geophysical signatures resolving hydrogeological complexities over hard rock terrain — a study from Southern India. Arab J Geosci (2014) 7:2249-2256 DOI 10.1007/s12517-013-0931-4

Sonkamble S, Rangarajan R, Rajkumar R, Warsi T, Rao TS, Ahmed S (2020 Appraising hydro-dynamics of alluvial aquifers from Indo-Gangetic Plains. Journal of the Geological Society of India 94 (5), 464-470

Sophocleous M, Ma T (1998) A decision support model to assess vulnerability to salt water intrusion in the great bend prairie aquifer of Kansas. Ground Water 36(3):476-483 Surinaidu, L, Charles, G.D, Bacon, Pavelic, Paul (2013) Agricultural groundwater management in the Upper Bhima Basin: current status and future scenarios. Hydrol. Earth Syst. Sci, 17 (507-517) (2013), p. 2013

Stummer P, Maurer H, Green AG (2004) Experimental design: electrical resistivity data sets that provide optimum subsurface information. Geophysics 69 (1), 120e139. https://doi.org/10.1190/1.1649381.

Taylor R, Howard K (2000) A tectono-geomorphic model of the hydrogeology of deeply weathered crystalline rock: evidence from Uganda. Hydrogeology Journal, 8(3), 279-294.

Tiwari VM, Wahr J, Swenson S (2009) Dwindling groundwater resources in northern India, from satellite gravity observations. Geophysical Research Letters, Vol. 36, L18401

Uddameri V, Hernandez EA, Estrada F (2013) A fuzzy simulation-optimization approach for optimal estimation of groundwater availability under decision maker uncertainty. Environ Earth Sci. doi:10.1007/s12665-0132905-y

Uhlemann S, Laura O, Richards LA, Naden E, Polya DA (2017) Electrical resistivity tomography determines the spatial distribution of clay layer thickness and aquifer vulnerability, Kandal Province, Cambodia. J. Asian Earth Sci. 147, 402e414.

Umar R, Ahmed I (2009) Sustainability of a shallow aquifer in Yamuna-Krishni interstream region, Western Uttar Pradesh, India: a quantitative assessment. IAHS publication, 20, 103.

WDA (2019) World Data Atlas. https://knoema.com/atlas/India

Wright EP (1992) The hydrogeology of crystalline basement aquifers in Africa. Geological Society, London, Special Publications, 66(1), 1-27.

Wyns R, Gourry JC, Baltassat JM, Lebert F (1999) Caractérisation multiparamètres des horizons de subsurface (0-100 m) en contexte de socle altéré. In 2e Colloque GEOFCAN, BRGM, IRD, UPMC,pp. 105-110 


\section{$\underline{\text { Declarations }}$}

Funding: The study was funded by World Wide Fund for Nature-India (WWF-India)

Conflicts of interest/Competing interests: We have no conflict of interest associated with this paper

Availability of data and material: Can be shared upon request to corresponding author

Code availability : Not applicable

\section{Authors' contributions:}

1) Dr. SA Mizan: Has developed the decision support tool and conceptualized the paper

2) Dr. S. Sonkamble: Acquired field hydro-geophysical data, analysis and interpretation. Framing the paper, English corrections.

3) Ms. A. Sharada: Carried out groundwater modelling

4) Mr. Md. Wajihuddin: Prepared GIS maps, contour maps, data analysis and involvement in field data collection

5) Mr.S. Roy: Social hydrology and rainfall data collection, stakeholders information

6) Mr. M. Dhar: Social hydrology and rainfall data collection, stakeholders information

Ethics approval : We comply with Ethical Standards

Consent to participate: Obtained

Consent for publication : Obtained 
Figures

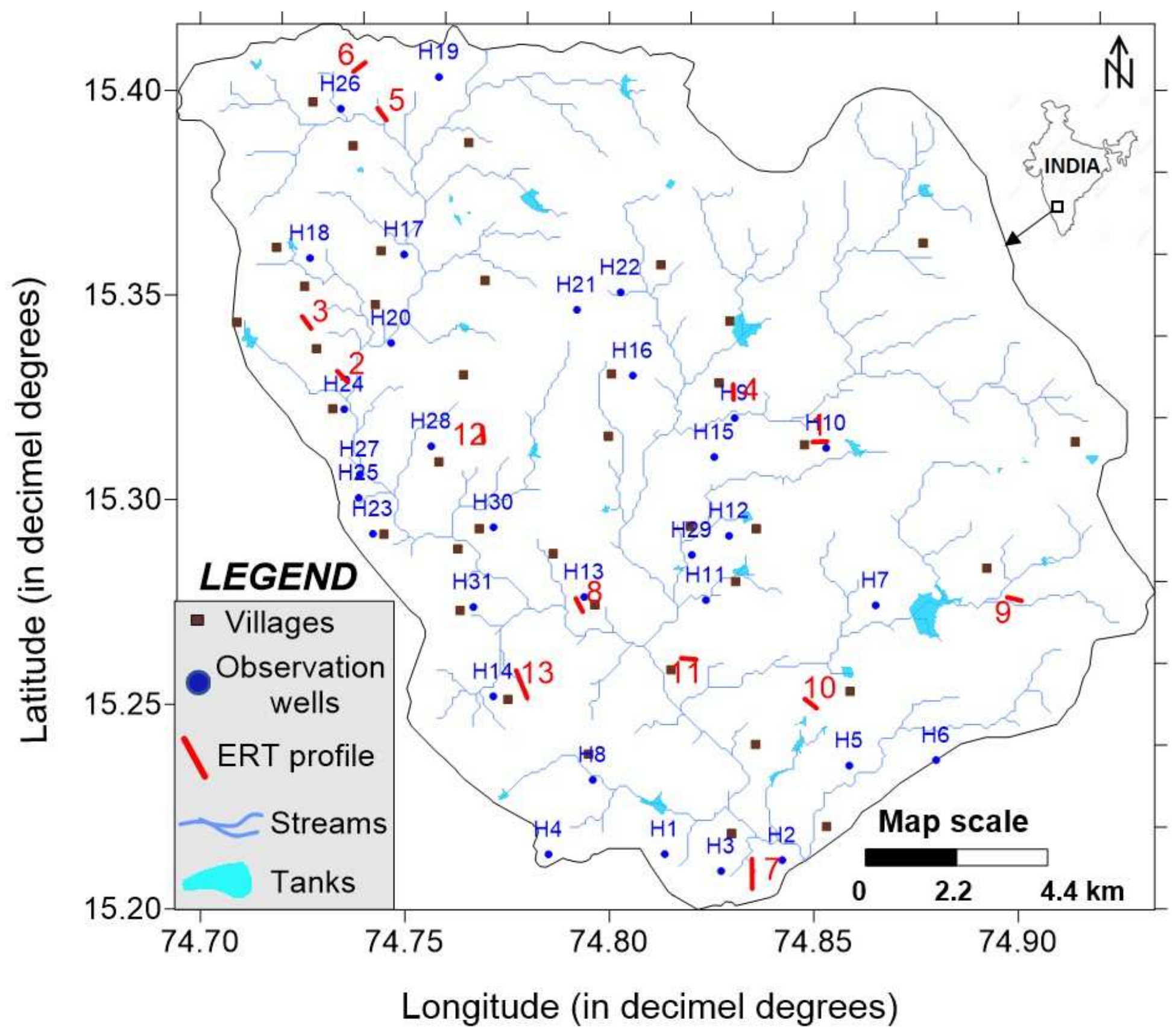

Figure 1

Location map of the study area including the hydro-geophysical investigations Note: The designations employed and the presentation of the material on this map do not imply the expression of any opinion whatsoever on the part of Research Square concerning the legal status of any country, territory, city or area or of its authorities, or concerning the delimitation of its frontiers or boundaries. This map has been provided by the authors.

Figure 2 
Images showing, (a) digital elevation model (DEM) derived from SRTM data, and (b) land use and land cover (LULC) of the study area derived from IRS LISS-III satellite image Note: The designations employed and the presentation of the material on this map do not imply the expression of any opinion whatsoever on the part of Research Square concerning the legal status of any country, territory, city or area or of its authorities, or concerning the delimitation of its frontiers or boundaries. This map has been provided by the authors.

\section{Figure 3}

Field snaps showing (a) sugarcane farm land, (b) deep bore well as irrigation source, (c) groundwater discharge, (d) sugarcane harvesting, (e) \& (f) fractures in the out crops of the hard rock. Theses fractures serve as potential recharge sites for groundwater. 


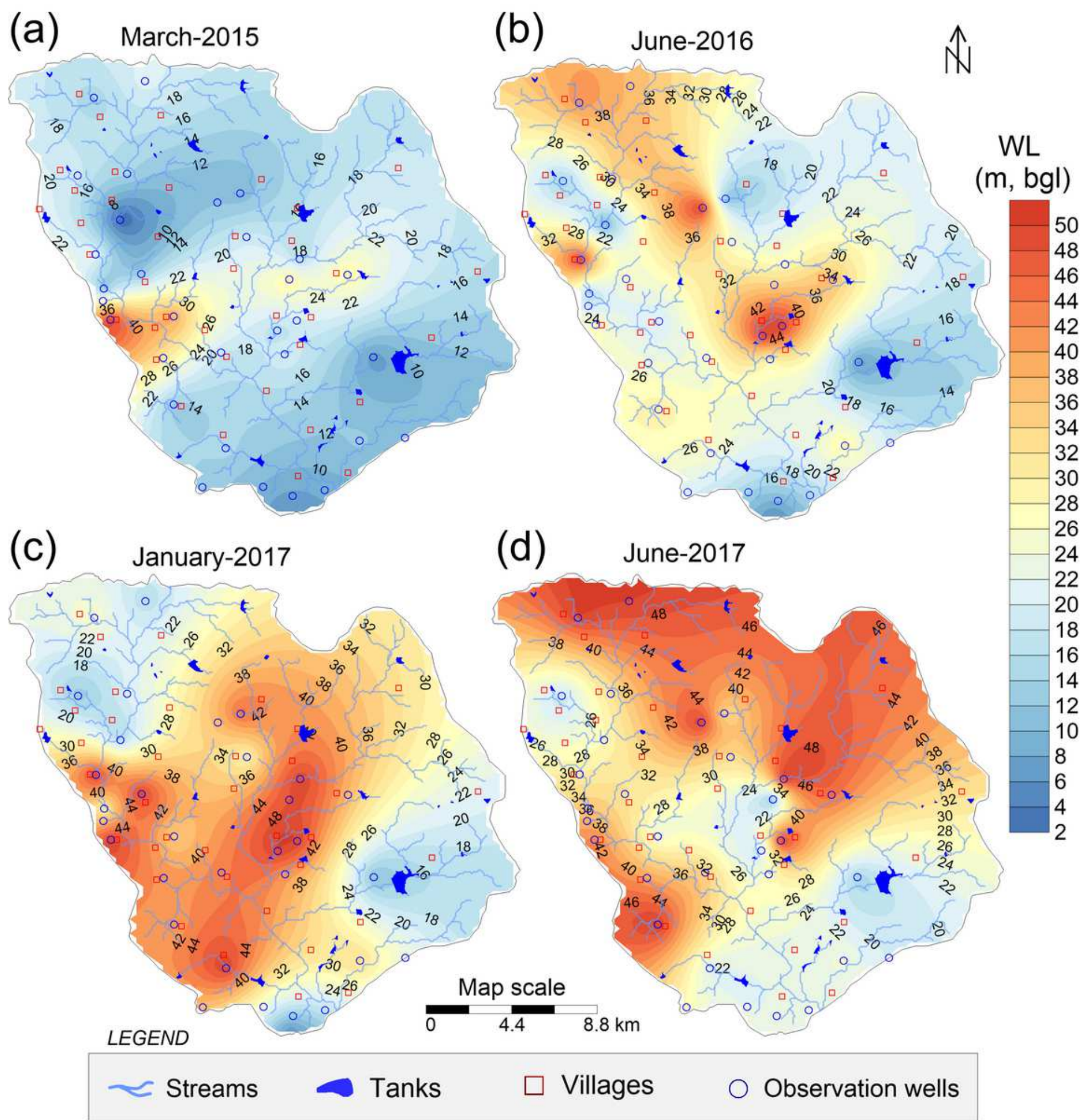

\section{Figure 4}

Contour map showing the water level ( $\mathrm{m}, \mathrm{bgl}$ ) of (a) pre-monsoon-2015 (b) pre-monsoon 2016, (c) postmonsoon 2017, and (d) pre-monsoon 2017 in the study area. Note: The designations employed and the presentation of the material on this map do not imply the expression of any opinion whatsoever on the part of Research Square concerning the legal status of any country, territory, city or area or of its 
authorities, or concerning the delimitation of its frontiers or boundaries. This map has been provided by the authors.

(a) Iteration $3 \mathrm{RMS}$ error $5.1 \%$ Electrodes spacing in meters

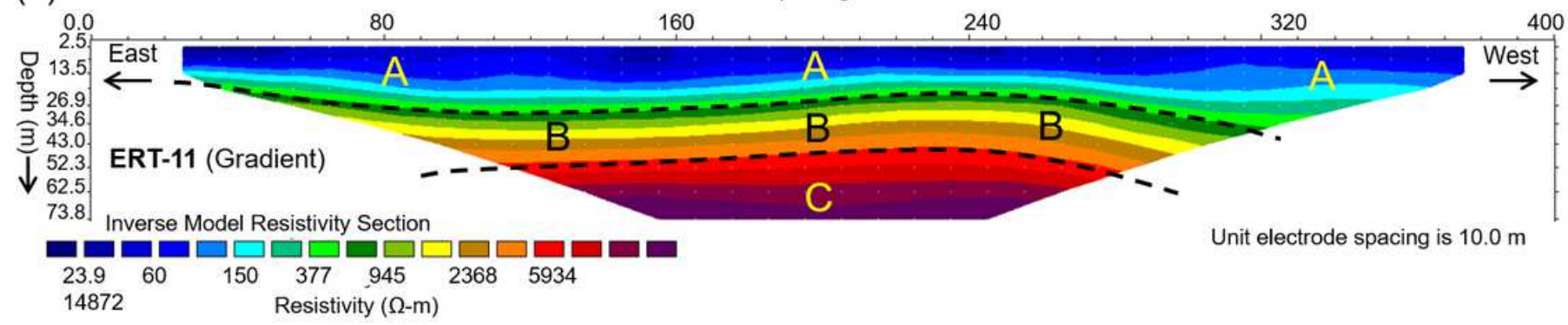

(b) Iteration 3 RMS error $6.4 \%$

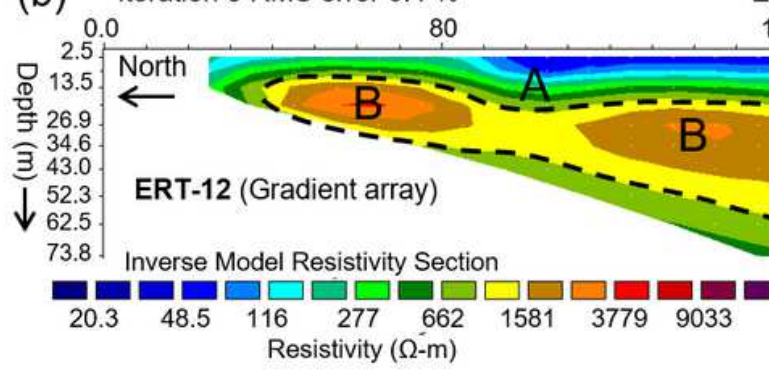

Electrodes spacing in meters

$160 \quad 240$

320

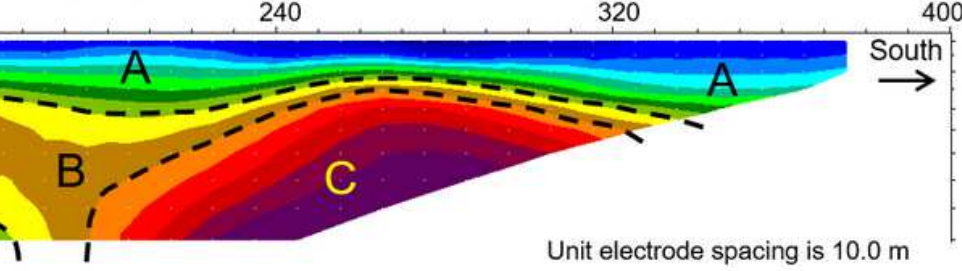

Unit electrode spacing is $10.0 \mathrm{~m}$

\section{LEGENDS}

$$
\begin{aligned}
& \text { A - Top soil and weathered zone (Unconfined aquifer) } \\
& \text { B - Saturated fractured zone (Confined aquifer) } \\
& \text { C - Massive hard rock (Aquifuge) }
\end{aligned}
$$

\section{Figure 5}

Inverse model resistivity sections (IMRS) of the ERTs with hydro-lithological information from (a) Mugodikoppa village (ERT-11), and (b) Haliyal village (ERT-12) in the study area 

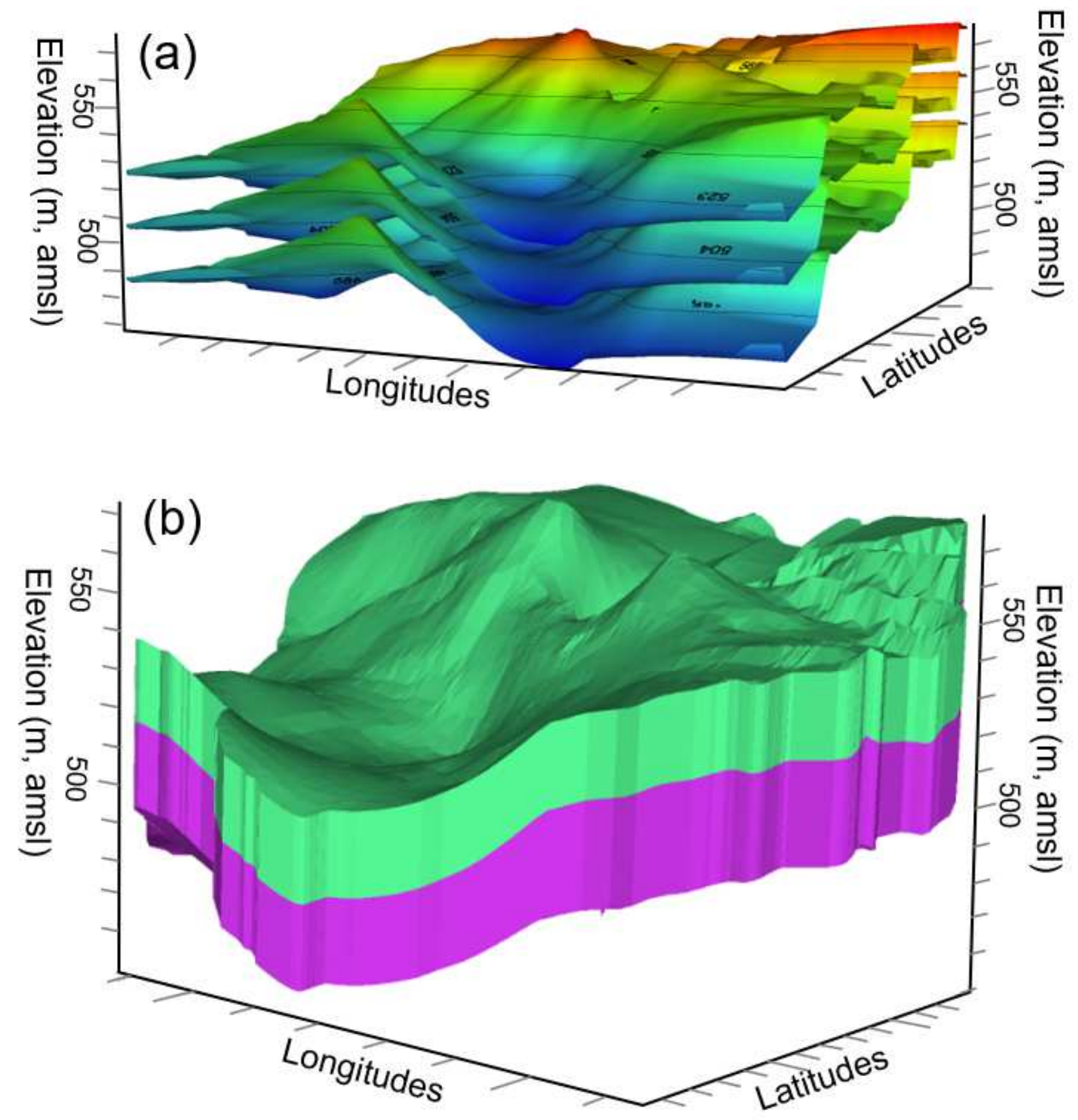

Figure 6

Models showing (a) Layering system in the watershed, and (b) 3-dimensional discretization of the 2-layer model 


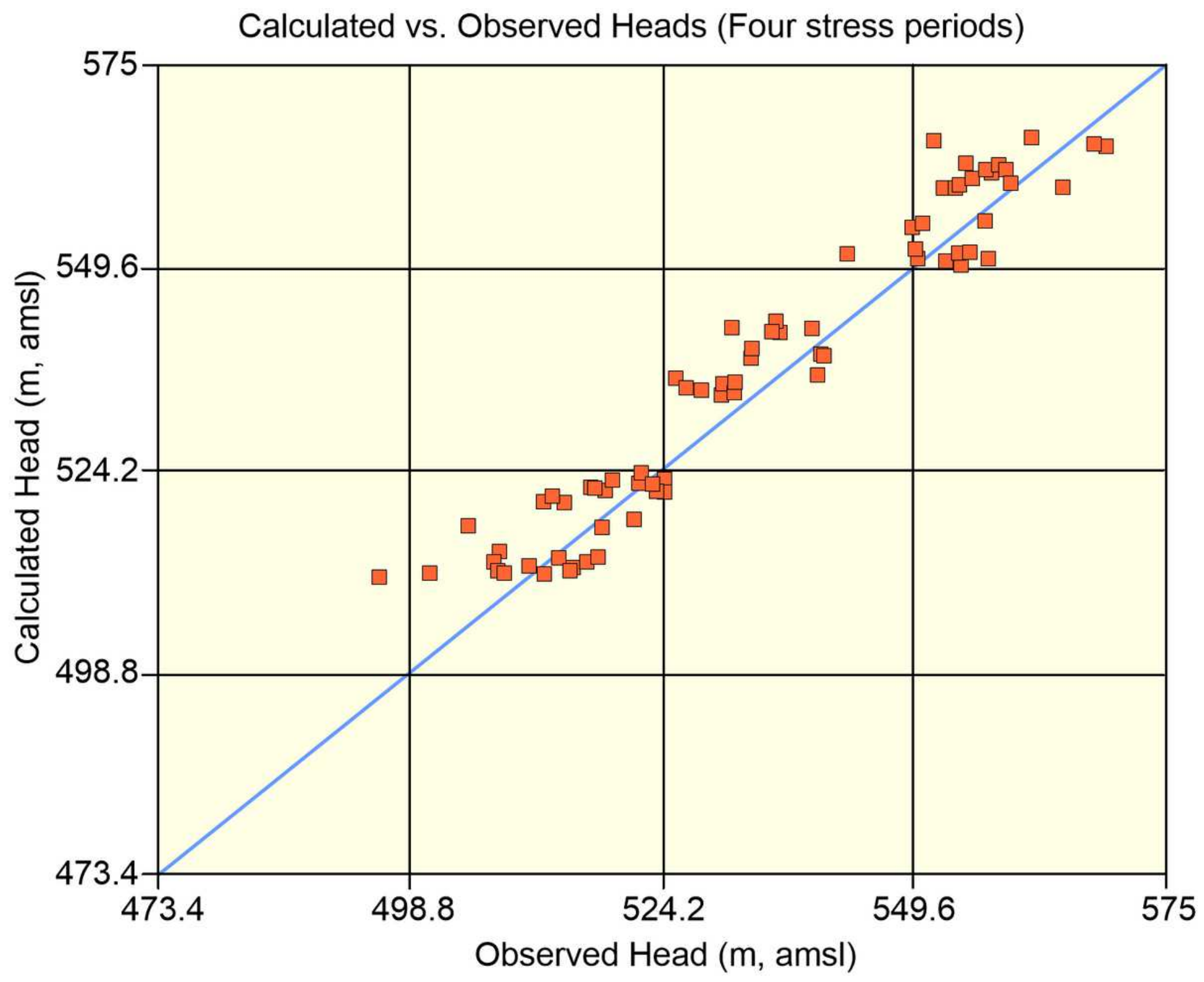

Min. Residual: $0.042(\mathrm{~m})$ at $014 / 14$ Time $=0$ Max. Residual: $15.39(\mathrm{~m})$ at $05 / 5$ Time $=797$ Residual Mean: $2.94(\mathrm{~m})$

Abs. Residual Mean: $4.63(\mathrm{~m})$
Standarad Error of the Estimate: $0.54(\mathrm{~m})$ Root Mean Squared: $5.53(\mathrm{~m})$ Normalized RMS: 7.57 (\%) Correlation Coefficient: 0.97

Figure 7

Calibration results with normalized RMS Error $7.57 \%$ for four stress period. 


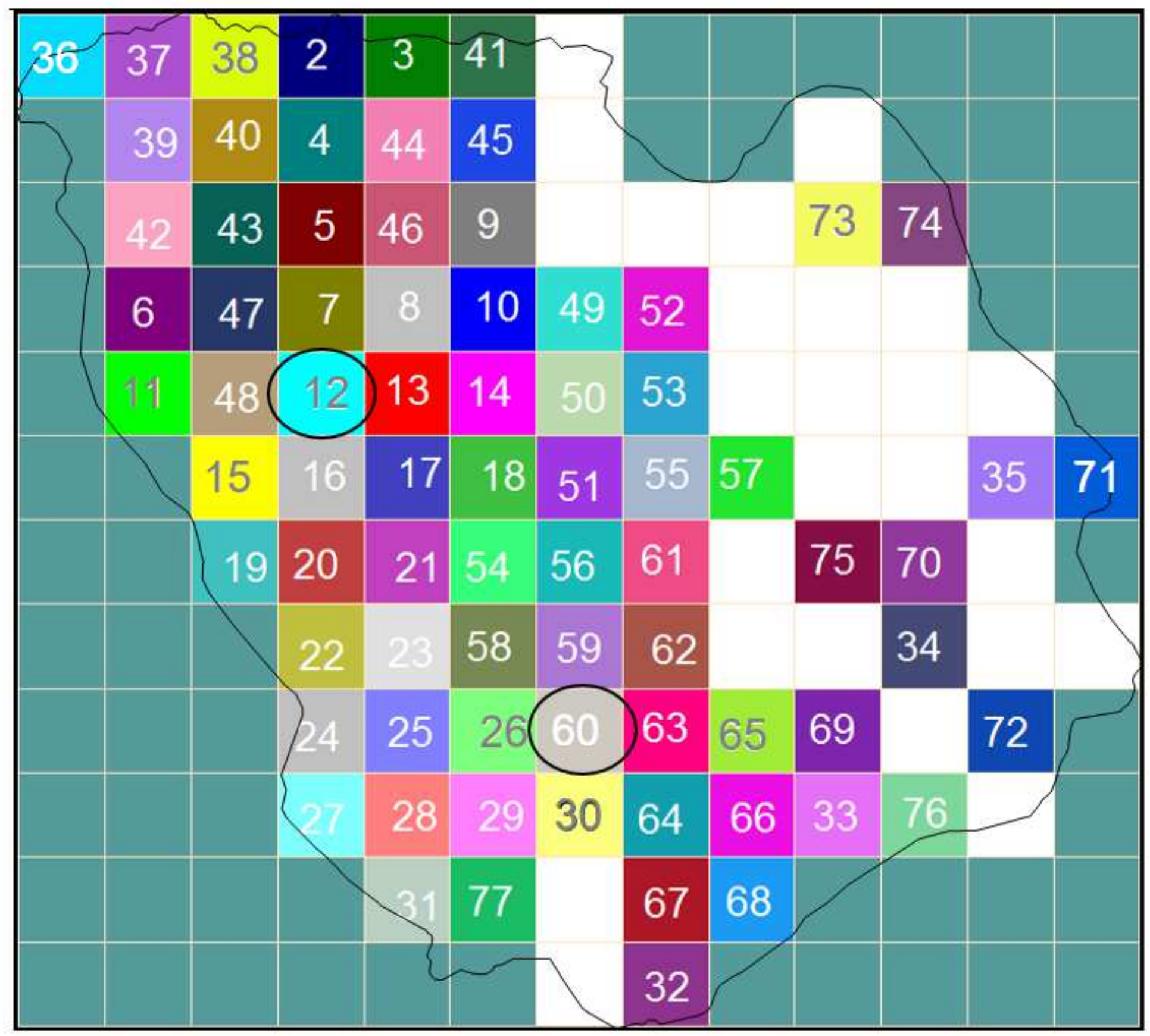

Figure 8

Selected cells for groundwater management at $2 \mathrm{~km} \times 2 \mathrm{~km}$ scale in Tattihalla watershed based on the sugarcane land use. The cells 12 and 60 marked on the image are presented in this paper for projecting future water scenarios with various pumping patterns 

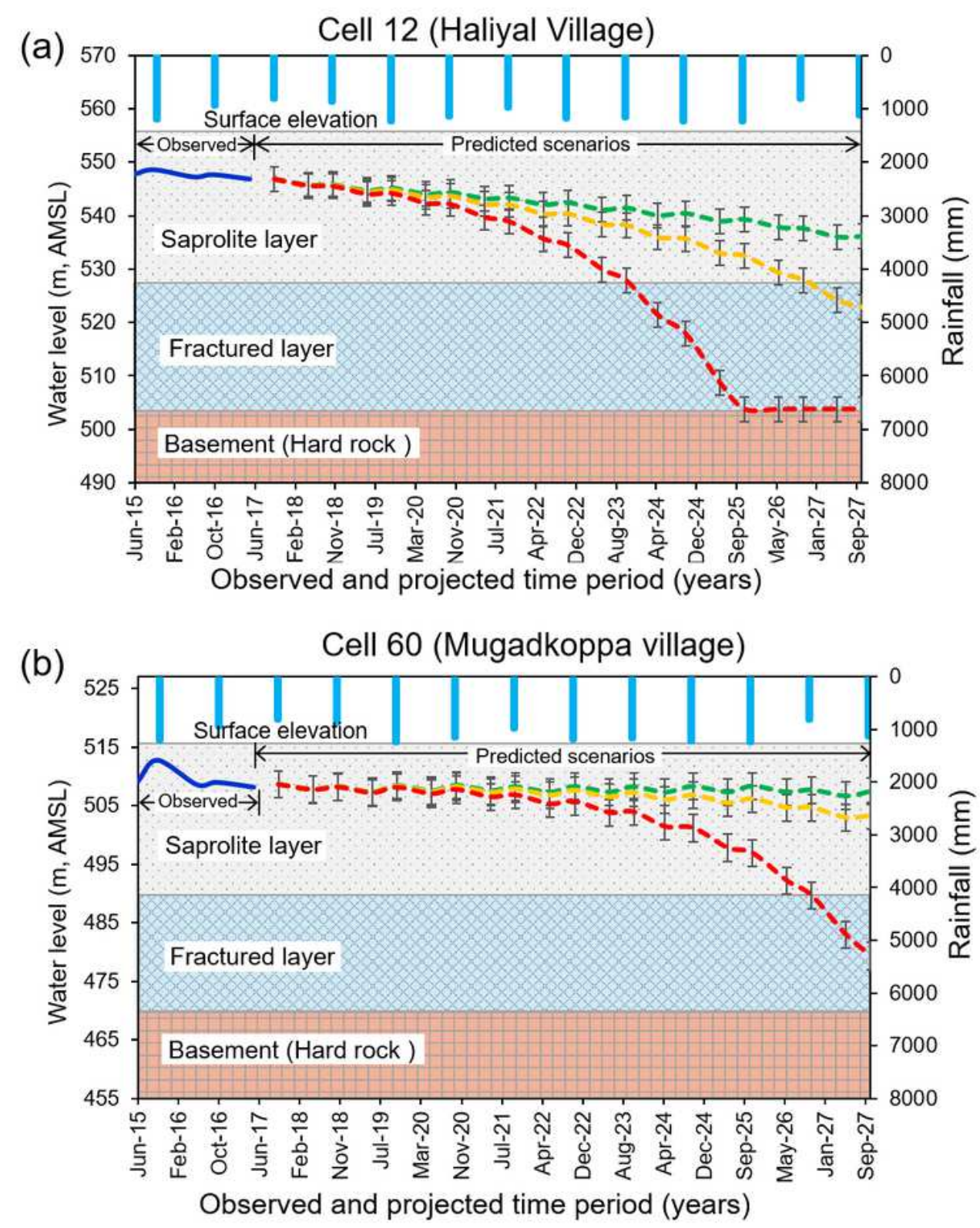

LEGENDS

- Rainfall (mm)
- Observed water level (m, AMSL)
--- Scenarion-1 (10\% Pumping increased)
--- Scenarion-2 (25\% Pumping increased)
--- Scenarion-3 (50\% Pumping increased)

\section{Figure 9}

Projection of future water level with 10\%, 20\% \& 30\% increased pumping rates at (a) cell-12 (Haliyal village), and (b) cell-60 (Mugodikoppa village). 

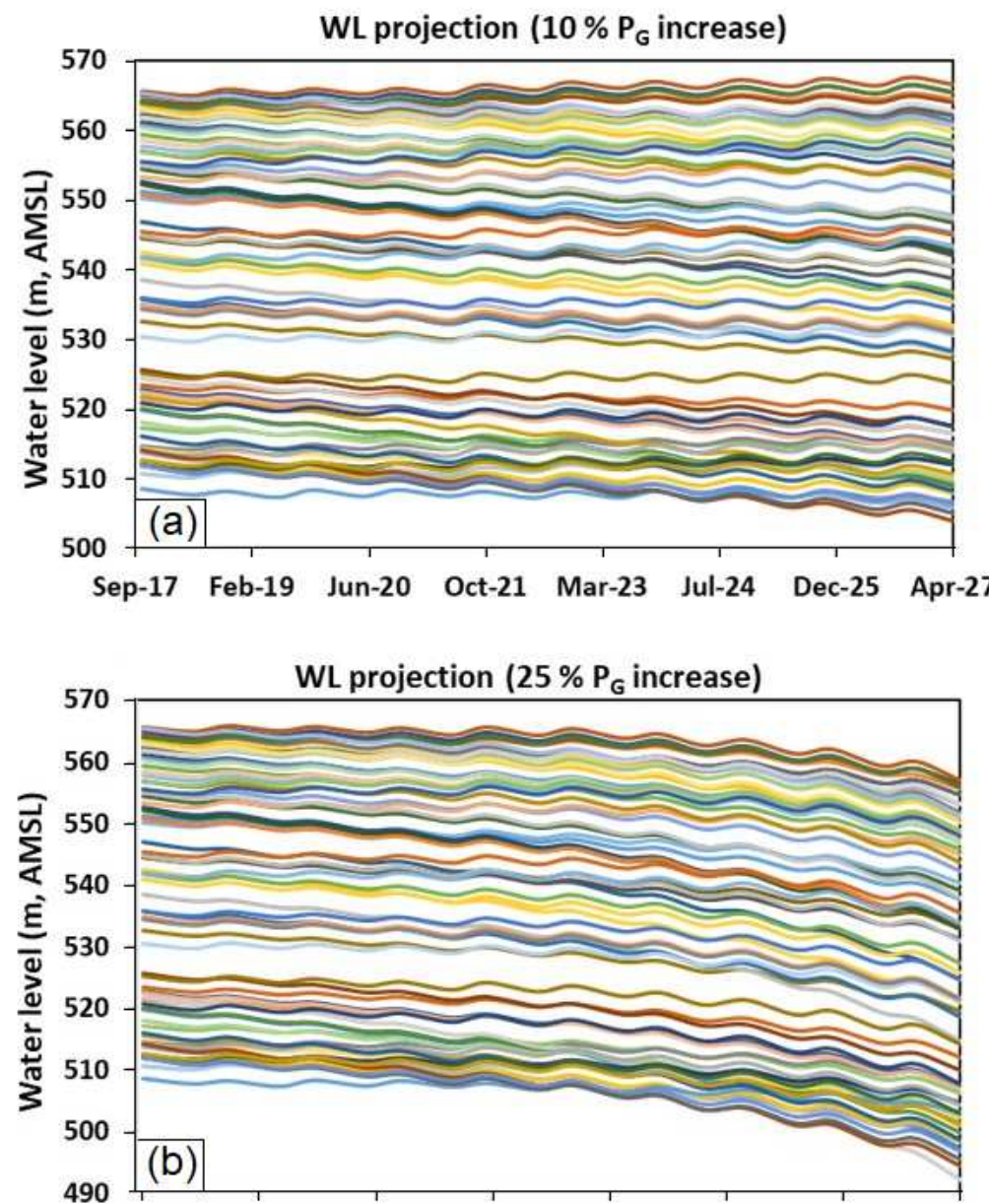

Sep-17 Feb-19 Jun-20 Oct-21 Mar-23 Jul-24 Dec-25 Apr-27

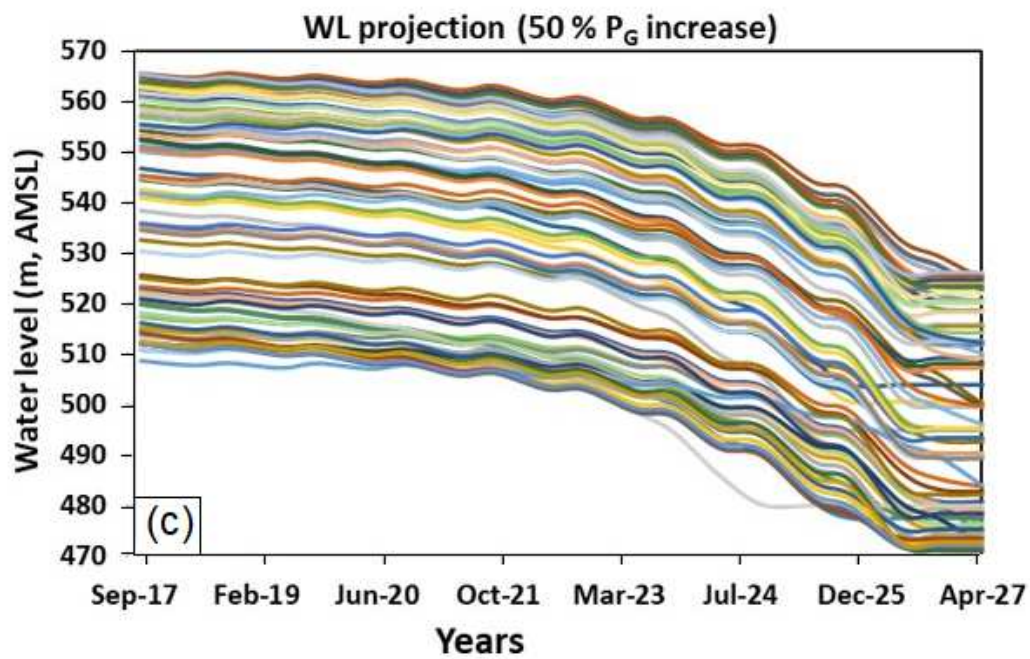

Figure 10

Projection of future water level at all the 76 cells with increased pumping rates of (a) $10 \%$, (b) $20 \%$, and (c) $30 \%$ 